\title{
Occurrence and Hydrochemical Characteristics of Saline and Salty Springs in the Sichuan Basin of China
}

\author{
Juan Guo, ${ }^{1}$ Xun Zhou $\mathbb{D}^{1},{ }^{1,2}$ Yuqi Zhang, ${ }^{1}$ Mingming Ta, ${ }^{1}$ and Yuan Wang ${ }^{1}$ \\ ${ }^{1}$ School of Water Resources and Environment, China University of Geosciences (Beijing), Beijing, China \\ ${ }^{2}$ MOE Key Laboratory of Groundwater Circulation and Environmental Evolution, China University of Geosciences (Beijing), \\ Beijing, China
}

Correspondence should be addressed to Xun Zhou; zhouxun@cugb.edu.cn

Received 17 October 2018; Revised 10 January 2019; Accepted 12 March 2019; Published 9 May 2019

Academic Editor: Henrik Drake

Copyright ( 2019 Juan Guo et al. This is an open access article distributed under the Creative Commons Attribution License, which permits unrestricted use, distribution, and reproduction in any medium, provided the original work is properly cited.

Water samples from saline and salty springs (geothermal wells, $n=64$ ) with TDS of $2-83 \mathrm{~g} / \mathrm{L}$ and temperature of $19-95^{\circ} \mathrm{C}$ were collected in the Sichuan Basin to explore the factors controlling the occurrence of the springs and the differences in hydrochemistry. The saline and salty springs mostly emerge at the margin of the basin where fault zones or anticlines occur, which are clearly controlled by the regional tectonic trend. The springs are mainly of $\mathrm{SO}_{4}-\mathrm{Na}$ type in the western basin, $\mathrm{SO}_{4}-\mathrm{Ca} \cdot \mathrm{Na}$ and $\mathrm{HCO}_{3}-\mathrm{Na}$ type in the southwestern basin, $\mathrm{Cl}-\mathrm{Na}$ and $\mathrm{Cl} \cdot \mathrm{SO}_{4}-\mathrm{Na}$ type in the northeastern basin, and $\mathrm{SO}_{4}$-Ca type in the eastern basin. Good correlation between $\mathrm{Na}$ and $\mathrm{Cl}, \mathrm{Ca}$ and $\mathrm{SO}_{4}$, and $\mathrm{Mg}$ and $\mathrm{SO}_{4}$ suggests that the major ions of springs in the Sichuan Basin are from incongruent dissolution of halite, gypsum, dolomite, and magnesium sulfate minerals present in the outcropping Cretaceous and Triassic and Permian strata (sandstone, gypsum, or anhydrite layers or lens) in the western basin. The presence of marine carbonate (limestone and dolomite) interbedded with evaporites (gypsum and halite) in the eastern basin explains the good correlations between $\mathrm{SO}_{4}$ and $\mathrm{Ca}$ and between $\mathrm{Na}$ and $\mathrm{Cl}$. The groundwater is continuously heated by geothermal heat flow. A conceptual model for the formation of the saline and salty springs is proposed that hypothesizes meteoric water infiltrates in the core of anticlines that occur in the carbonate rocks with fractures or in the fault zones. The water flows into the limbs of the anticlines or deep aquifers along fault planes. During its subsurface transport, incongruent dissolution of carbonates and evaporites (including anhydrite and halite) in the Lower and Middle Triassic strata occurs and the groundwater is heated. The discharge areas are often in the low-lying areas along the limbs of anticlines where carbonate rocks crop out, in the low-lying areas of local river valleys that cut noncarbonate rocks, or in the Yangtze Valley and its tributaries where groundwater flows upward through the Upper Triassic clastic rocks.

\section{Introduction}

Groundwater mineralization is strongly conditioned not only by the nature of aquifers but also by the size and residence time within a groundwater system $[1,2]$. Halite dissolution, connate water, and geological membrane filtration are recognized as three sources of salinity in groundwater in sedimentary basins [3-6]. In the sedimentary Sichuan Basin, subsurface brines and saline or salty springs $(>35 \mathrm{~g} / \mathrm{L})$ of different hydrogeochemical characteristics coexist in the Mesozoic formations. Subsurface brine, enriched in elements such as $\mathrm{K}, \mathrm{Br}, \mathrm{I}, \mathrm{Li}, \mathrm{Sr}, \mathrm{Ba}, \mathrm{Cs}$, and $\mathrm{Rb}$, is an important raw material for agricultural and industrial purposes and is characterized by high total dissolved solids (TDS) ranging from tens to hundreds of grams per liter [7-9]. The chemical and isotopic compositions of subsurface brines provide important information on evaporation and subsurface dissolution processes, which are of great significance to the deposition of ancient evaporites and other ores [10].

Saline or salty springs are natural discharge of groundwater at the surface that can provide significant information about hydrogeochemical processes and geothermal processes in the subsurface $[11,12]$. Bryan [13] and Alfaro and Wallace [14] put forward a classification system of springs based on 
the source of water, temperature, mineral compositions, aquifer lithology, and structure. Springs can be divided into cold springs $\left(<20^{\circ} \mathrm{C}\right)$, warm springs $\left(20-50^{\circ} \mathrm{C}\right)$, hot springs $\left(>50^{\circ} \mathrm{C}\right)$, and boiling springs depending on temperature. Glazier [12] further summarized the classification of spring waters considering geology, hydrology, mineralization, water temperature, ecology, and human use. The classification of the springs includes freshwater springs $(<1 \mathrm{~g} / \mathrm{L})$, mineral springs $(1-35 \mathrm{~g} / \mathrm{L})$, and saline springs $(>35 \mathrm{~g} / \mathrm{L})$ according to TDS. Naik et al. [15] suggested an expanded spring classification based on the nature of emergence and source aquifers, which further enriched the classification of springs. In China, springs are typically classified as 4 types according to TDS, which are freshwater springs (TDS $<1 \mathrm{~g} / \mathrm{L}$ ), brackish springs (1-10g/L), saline springs $(10-35 \mathrm{~g} / \mathrm{L})$, and salty springs $(>35 \mathrm{~g} / \mathrm{L})$, and 4 types based on temperature, including cold springs which the temperature is significantly lower than local multiyear average temperature, ambient temperature of springs which the temperature is closed to local multiyear average temperature, hot springs $\left(25-60^{\circ} \mathrm{C}\right)$, and boiling springs ( $\geq$ local boiling point). Hot springs can be further divided into 3 types, including low-temperature hot springs $\left(25-40^{\circ} \mathrm{C}\right)$, low-to-medium-temperature hot springs $\left(40-60^{\circ} \mathrm{C}\right)$, and medium-temperature hot springs (60-local boiling point) [16]. Generally, the temperature of $25^{\circ} \mathrm{C}$ is considered as a multiyear average temperature in China. In this paper, we classify the springs in the Sichuan Basin with TDS ranging from $2 \mathrm{~g} / \mathrm{L}$ to $35 \mathrm{~g} / \mathrm{L}$ and temperature greater than $25^{\circ} \mathrm{C}$ as saline hot springs and TDS greater than $35 \mathrm{~g} / \mathrm{L}$ and temperature greater than $25^{\circ} \mathrm{C}$ as salty hot springs.

The TDS of the saline and salty springs, including geothermal wells in the Sichuan Basin, range from a few grams per liter to several tens of grams per liter, and the temperature of the springs varies from normal temperature to more than $90^{\circ} \mathrm{C}$. Most of the springs reach the standards of hot springs of low-to-medium temperature, such as the Wenquanzhen springs [17] in Kaixin County of northeastern Chongqing, Xiaogu springs in Qianwei of the central Sichuan Basin, Luofushan springs in Mianyang of the northwestern Sichuan Basin, and Zhougongshan springs in Ya'an of the southwestern Sichuan Basin [18]. Some saline and salty springs in the Sichuan Basin have been used to produce salt and a unique salt culture developed in the past centuries. Some of the springs of medium to high temperature have been developed for warm and hot springs resorts in the past decades.

At present, analyzing the origin, evolutionary processes, and genesis of spring waters by means of isotope and ion ratios combined with geological conditions are common research strategies [19-21]. For cases where there are many water samples, statistical analysis is a quantitative tool that is used to study the correlations of chemical parameters to classify the water sample points, to examine the controlling factors and correlations of ions, and to evaluate the similarities among the spring sampling sites. This method can identify the chemical characteristics of springs on a statistically significant basis [22-24]. For example, Kloppmann et al. [25] explored the sources of brine, groundwater, and surface water in the vicinity of a Permian salt dome in the Northern Germany that originated from dissolution of evaporites, silicate, and halite by analyzing hydrochemistry and isotopic tracing. Pilla et al. [26] identified the recharge mechanisms, origin of groundwater, and the hydraulic conditions of deep aquifers in sedimentary basins in Northern Italy by using water hydrochemistry and stable isotopes. Zarei et al. [27] proposed the saline springs that emerge adjacent to the Konarsiah salt diapir in Zagros Mountains of Iran are derived from the mixing four end members of groundwater (sulfate water, carbonate fresh waters, and diapir brine). Li [28] examined the hydrochemical features of salty springs at Yanjinghe and Yantang in Sichuan Province and determined that the source of mineralizations is a result of halite dissolution with the correlation ion coefficients. Zhou et al. [29] discussed the water cycle processes of the Ningchang salty springs in Wuxi County in the eastern Sichuan Basin and summarized the schematic genetic model for the relatively high TDS of the salty spring.

The classification of saline and salty springs in the entire Sichuan Basin has not been systematically summarized. The Sichuan Basin is unusual because it has well-developed saltbearing strata. As a result, it is useful to explore the nature of any of hydrochemical zonation of the basin. This work is aimed at exploring the geological background for the occurrence and hydrochemical characteristics of the saline and salty springs in the Sichuan Basin through field investigations, sampling, and analysis bases on previous studies. We collected previously published physical and hydrochemical data of water samples from different regions of the basin. By comprehensively analyzing the geologic background conditions and the occurrence and basic hydrochemical and hydrodynamic conditions of the springs, we aim to acquire a new understanding of the genetic models of the saline and salty springs in this area. We believe this could provide some guidance for the exploration of potash salts and provide better understanding of the processes of energy and material migration in the hydrological cycle in the sedimentary basins.

\section{Description of the Study Area}

The Sichuan Basin, with an area of approximately $20 \times 10^{4}$ $\mathrm{km}^{2}$, is a huge intracratonic basin located in the eastern part of Sichuan Province and contains the independent municipalities of Chongqing in the southwestern China. The basin extends between latitude $28^{\circ} 00^{\prime}$ to $32^{\circ} 40^{\prime} \mathrm{N}$ and longitude $102^{\circ} 40^{\prime}$ to $100^{\circ} 00^{\prime} \mathrm{E}$. The basin has a subtropical monsoon humid climate with a mean summer temperature of 24$28^{\circ} \mathrm{C}$, a mean winter temperature of $4-8^{\circ} \mathrm{C}$, and a mean annual rainfall of $1000-1300 \mathrm{~mm}$. It is a rhombic-shaped sedimentary basin and has relatively uniform terrain, geological structure, and hydrogeology. Tectonically, the Sichuan Basin is a subunit of the northwestern Yangtze paraplatform, which has undergone multiphase tectonic events. The basin has undergone three evolutionary stages: the marine platform (the late Indosinian Event-Yanshan Event), the continental basin (the Chengjiang Event-the early period of the Indosinian Event), and the fold uplifting (the Himalayan Event) [30]. The basin is surrounded by the Micang Mountain Fold 

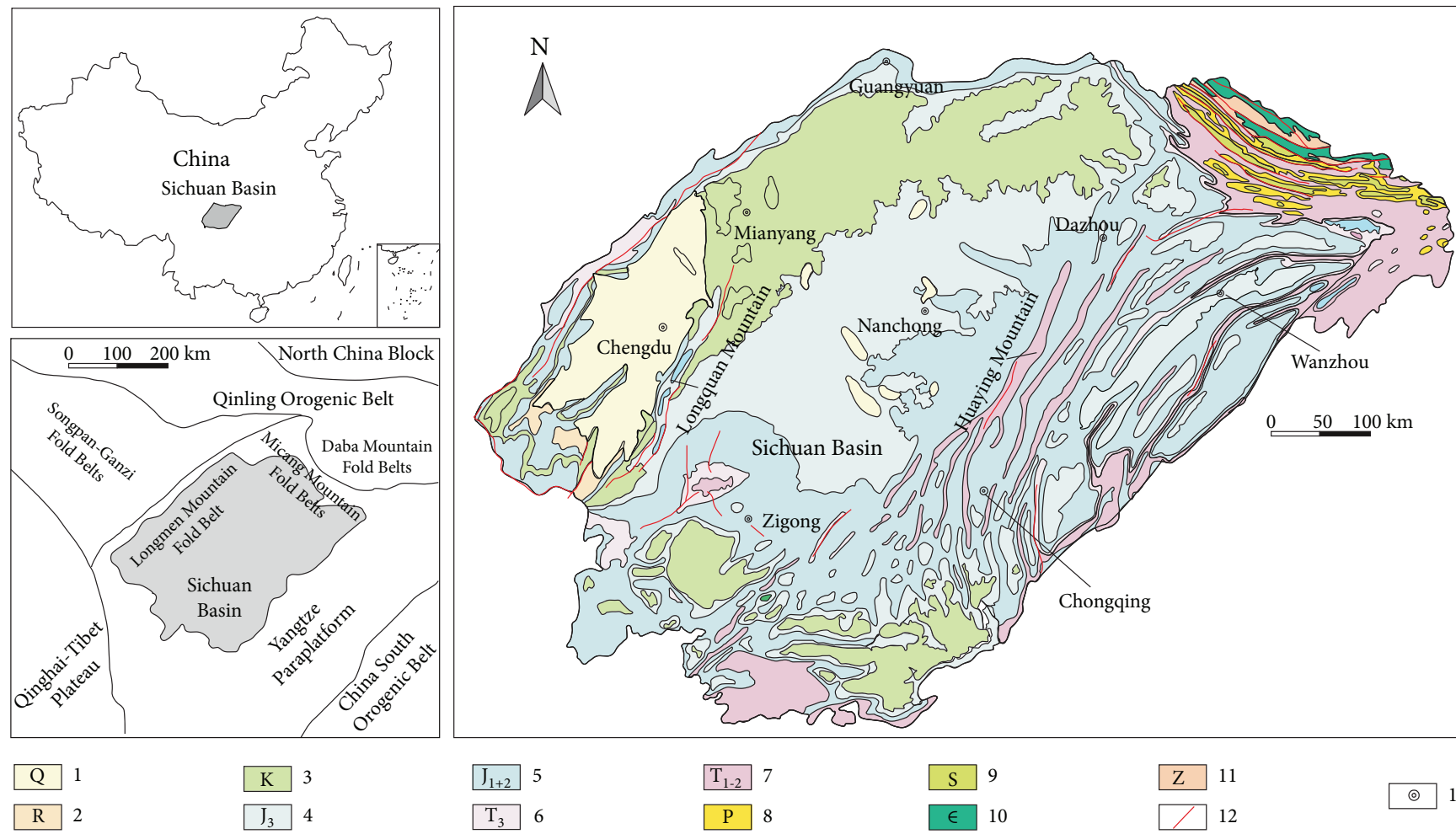

Figure 1: Simplified geological map of the Sichuan Basin (modified from the National Geological Map Database). 1: Quaternary sand and gravel; 2: Tertiary glutenite; 3: Cretaceous glutenite and mudstone; 4: Upper Jurassic sandstone and mudstone; 5: Middle and Lower Jurassic sandstone and mudstone; 6: sandstone and mudstone of the Upper Triassic Xujiahe Group; 7: carbonate of the Lower Triassic Jialingjiang Group and Middle Triassic Leikoupo Group; 8: Permian shale, killas, and tuff; 9: Siluria shale, killas, and mudstone; 10: Cambrian limestone and dolomite; 11: Neoproterozoic carbonate; 12: fault; 13: city.

Belt and Daba Mountain Fold Belt of the southern edge of the Qinling Orogenic Belt to the north, the Songpan-Ganzi Fold Belt and the Longmen Mountain Fold Belt of the eastern edge of the Qinghai-Tibet Plateau to the west, and the southern South China Orogenic Belt to the east and south [30] (Figure 1). The strata underlying the Sichuan Basin are characterized by thick layers from multiple depositional cycles in the vertical direction. The entire strata of the Sichuan Basin can be divided into two stages of sedimentary development: the Neoproterozoic to Middle Triassic marine sediments and the Late Triassic to Eocene continental sediments [31]. The marine sediments consist of a thick sequence of carbonate rocks, mudstone, sandstone, and evaporites. The continental sediments consist of clastic rocks [32,33] (Table 1).

The interior of the basin can be divided into three regions bounded by the Longquan Mountain Fault and the Huaying Mountain Fault. The area west of the Longquan Mountains forms a plain called the western Sichuan Basin and is underlain mainly by Quaternary sandstone and gravel and Cretaceous glutenite and mudstone, and sporadically by Jurassic sandstone and mudstone. The hilly area between the Longquan Mountains and the Huaying Mountains is known as the central Sichuan Basin. This area is underlain by Jurassic sandstone and mudstone and Cretaceous glutenite and mudstone [34]. The area to the east of the Huaying Mountains is called the eastern Sichuan Basin. This area contains Triassic carbonates and Jurassic sandstone and mudstone. A series of the ejective folds were formed the Sichuan Tectonic Event. The synclines in the eastern Sichuan Basin are covered by massive, thick Middle Jurassic sandstone and mudstone, and Middle and Lower Triassic carbonate rocks crop out in the cores of the anticlines.

The Early-Middle Triassic is one of the three main periods of deposition of salt-bearing formations (Sinian, Cambrian, and Early-Middle Triassic ages) in the Sichuan Basin [35] and comprises the main brine-bearing aquifers. The Triassic strata are characterized by multiple cycles of formations, which can be further divided into different groups based on depositional cycles. The Upper Triassic Xujiahe Group $\left(\mathrm{T}_{3} x\right)$ can be subdivided into six formations $\left(\mathrm{T}_{3} x^{1}\right.$, $\mathrm{T}_{3} x^{2}, \mathrm{~T}_{3} x^{3}, \mathrm{~T}_{3} x^{4}, \mathrm{~T}_{3} x^{5}$, and $\mathrm{T}_{3} x^{6}$ ) from bottom up. $\mathrm{T}_{3} x^{1}$, $\mathrm{T}_{3} x^{3}$, and $\mathrm{T}_{3} x^{5}$ are aquicludes consisting of shale, mudstone interbedded with siltstone, sandstone, and coal seams while $\mathrm{T}_{3} x^{2}, \mathrm{~T}_{3} x^{4}$, and $\mathrm{T}_{3} x^{6}$ are aquifers dominantly consisting of sandstone. The Middle Triassic Leikoupo Group $\left(\mathrm{T}_{2} l\right)$ and Lower Triassic Jialingjiang Group $\left(\mathrm{T}_{1} j\right)$ can be subdivided into four formations $\left(\mathrm{T}_{2} l^{1}, \mathrm{~T}_{2} l^{2}, \mathrm{~T}_{2} l^{3}\right.$, and $\left.\mathrm{T}_{2} l^{4}\right)$ and five formations $\left(\mathrm{T}_{1} j^{1}, \mathrm{~T}_{1} j^{2}, \mathrm{~T}_{1} j^{3}, \mathrm{~T}_{1} j^{4}\right.$ and $\left.\mathrm{T}_{1} j^{5}\right)$, respectively. The six formations of $\mathrm{T}_{1} j^{1}, \mathrm{~T}_{1} j^{3} \mathrm{~T}_{1} j^{5}-\mathrm{T}_{2} l^{1}, \mathrm{~T}_{2} l^{3}$, and $\mathrm{T}_{2} l^{4}$ are mainly salt-bearing formations, which are composed of marine carbonate (limestone and dolomite) interbedded with evaporites (gypsum and halite), and are characterized by parallel strata. The porosity mainly consists of karst voids and fissures [36]. The karst voids were formed by the dissolution of carbonate rocks. Most of the $\mathrm{T}_{1} j$ and $\mathrm{T}_{2} l$ formations crop out in the 


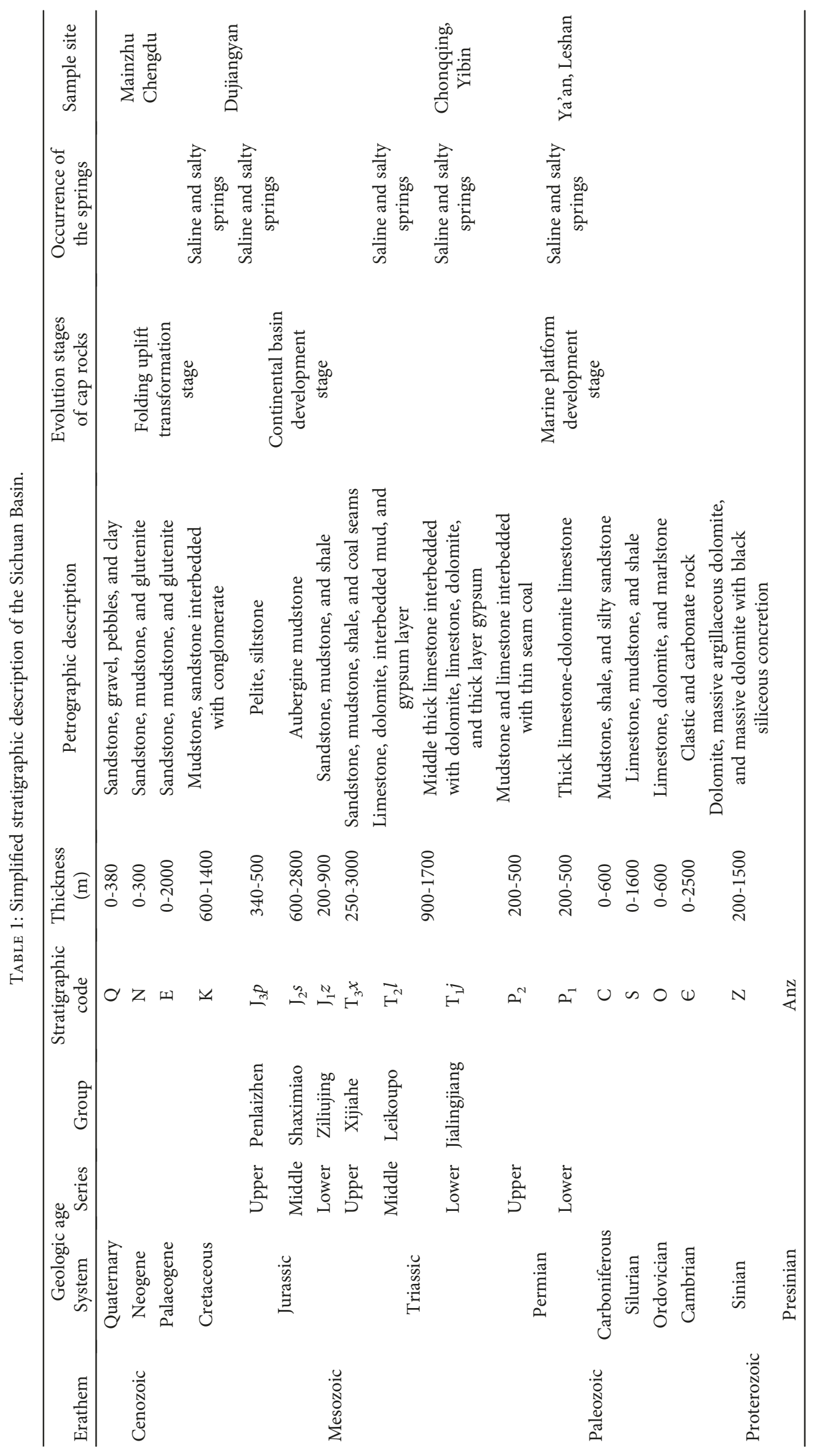




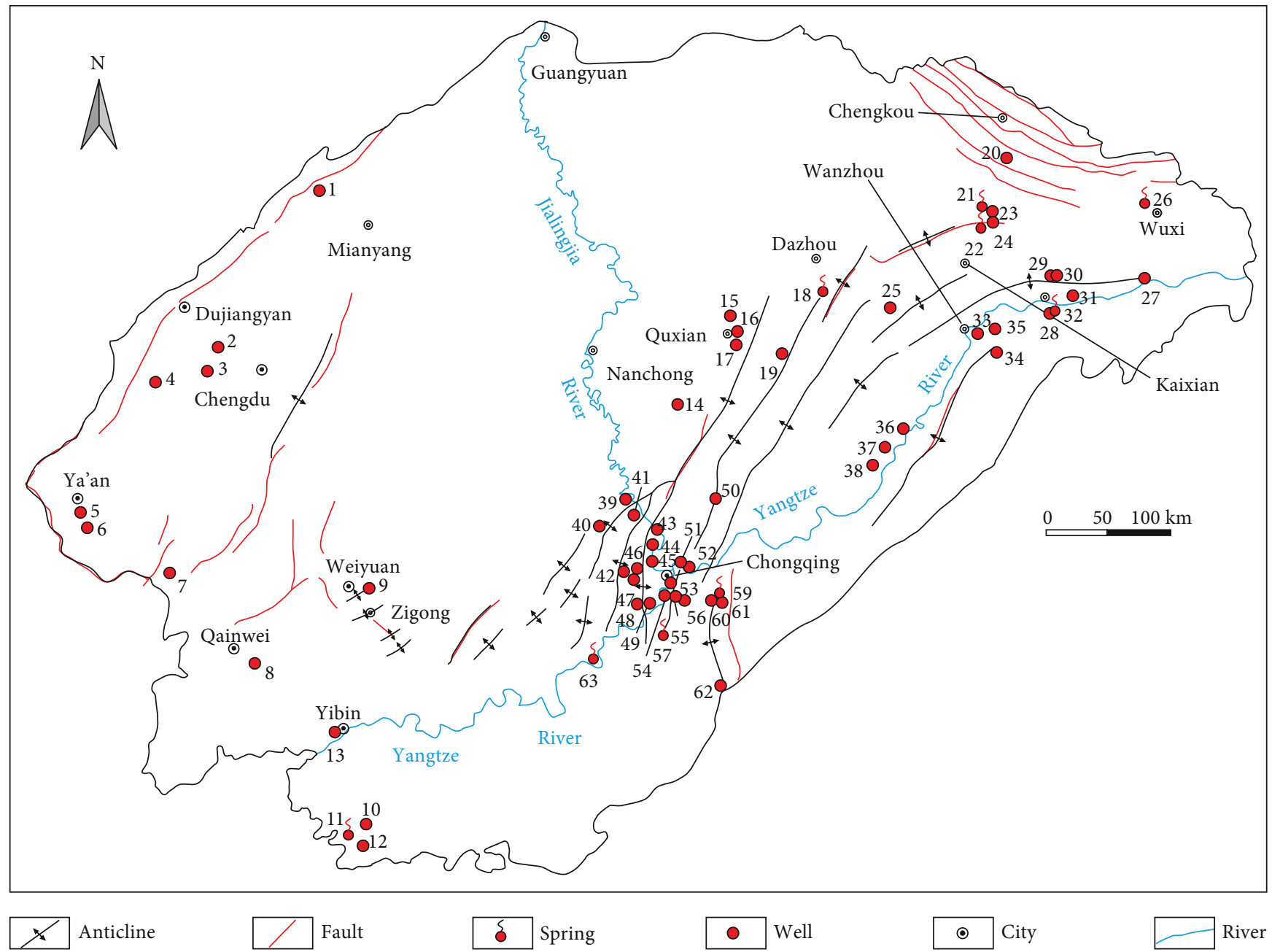

FIgURE 2: Location of the saline and salty springs in the Sichuan Basin.

anticline in the eastern Sichuan Basin. The $\mathrm{T}_{1} j$ and $\mathrm{T}_{2} l$ formations are buried in the western Sichuan Basin in small salt basins with good confinement [32]. Jurassic (J) strata occur in most of the Sichuan Basin. Cretaceous (K) strata occur in the western and southern Sichuan Basin. The Permian (P) formations crop out in parts of the eastern Sichuan Basin (Figure 1).

\section{Materials and Methods}

There are 64 representative natural springs and geothermal wells in the west, southwest, south, northeast, and east of the Sichuan Basin selected for this study. The locations of the springs and wells are shown in Figure 2. There are 50 water samples from the eastern and northeastern basins, accounting for $68 \%$ of the total samples. Field sampling was carried out over several years in the Sichuan Basin where temperature, $\mathrm{pH}$, and water temperature $(\mathrm{T})$ of the springs were measured in the field, which are about $70 \%$ of total data in this paper. The rest of the data (including nos. 1, 2, 7-9, 13$18,24,26,28,29,36-39$, and 62) shown in Table 2 are cited from the references [18, 22, 29, 35, 37, 38]. Measurements of $\mathrm{pH}$ and temperature were performed with $\mathrm{pH} \& \mathrm{ORP}$ meter
(CT-6821) (KEDIA, China) with accuracy of \pm 0.1 . The water samples were collected in plastic $550 \mathrm{~mL}$ and $1.5 \mathrm{~L}$ bottles, after rinsing with spring waters, for hydrochemical analyses. The measurements of ions were performed with ion chromatograph. The chemical analyses were conducted at the laboratory of the Beijing Brigade of Hydrogeology and Engineering Geology. The $\mathrm{K}$ and $\mathrm{Na}$ analyses were measured by the flame atomic absorption; $\mathrm{Cl}$ and $\mathrm{SO}_{4}$ were measured by the ion chromatogram; $\mathrm{Ca}$ and $\mathrm{Mg}$ were measured by the volumetric method (EDTA titration); $\mathrm{HCO}_{3}$ was measured by the volumetric method ( $\mathrm{HCl}$ titration).

\section{Characteristics of the Saline and Salty Springs in the Sichuan Basin}

Results of TDS of the saline and salty springs in the basin range from 2 to $82 \mathrm{~g} / \mathrm{L}$, temperature between $13^{\circ} \mathrm{C}$ and $95^{\circ} \mathrm{C}$, and $\mathrm{pH}$ from 7.05 to 8.4 (weakly alkaline) (Table 1), respectively. The differences between the TDS, $\mathrm{pH}$, and temperature of the saline or salty springs are related to the location occurrence of the springs, depth of groundwater circulation, residence time, hydrochemical processes, rock lithology, and the degree of the water alteration [39-41]. 


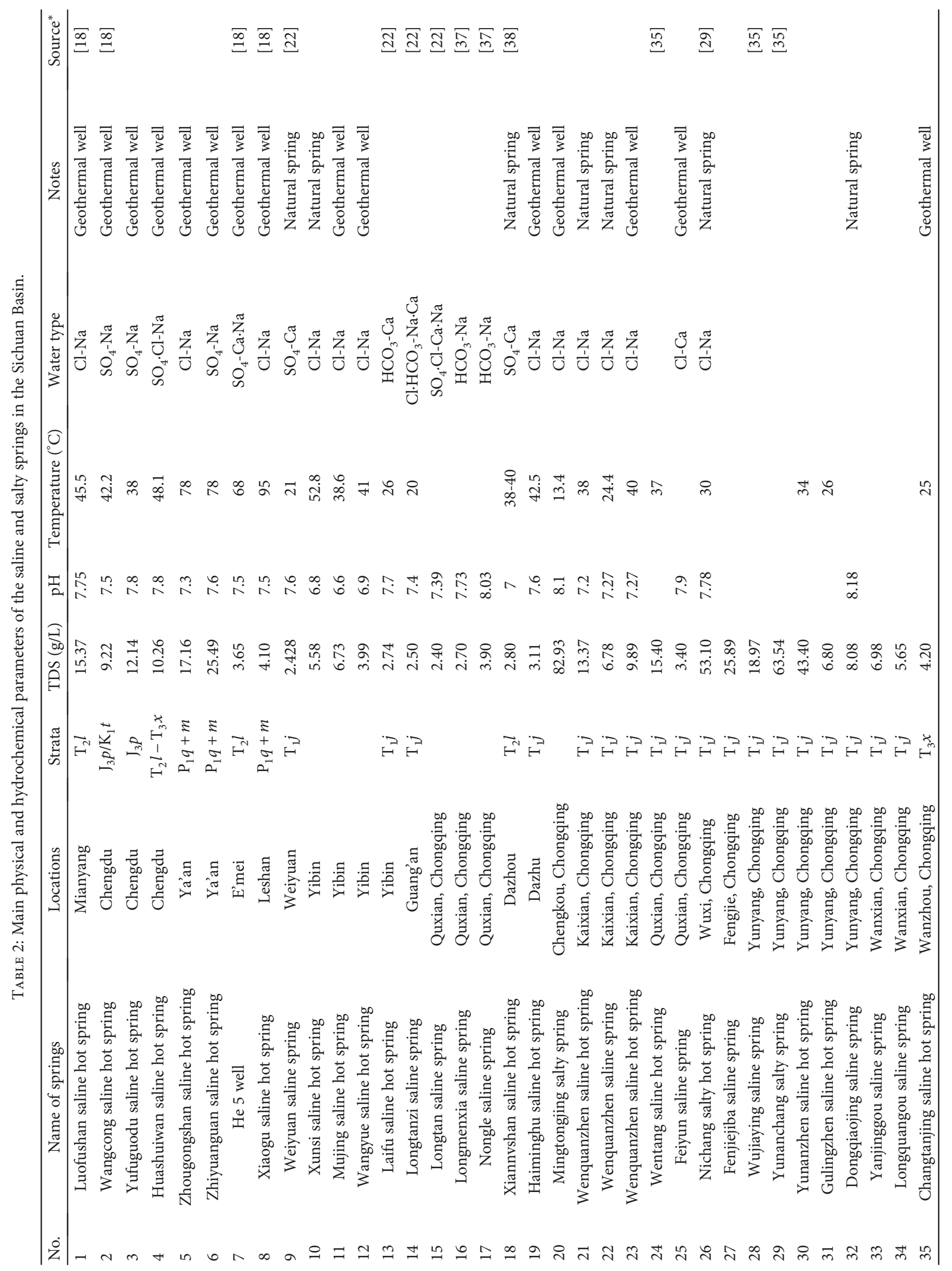




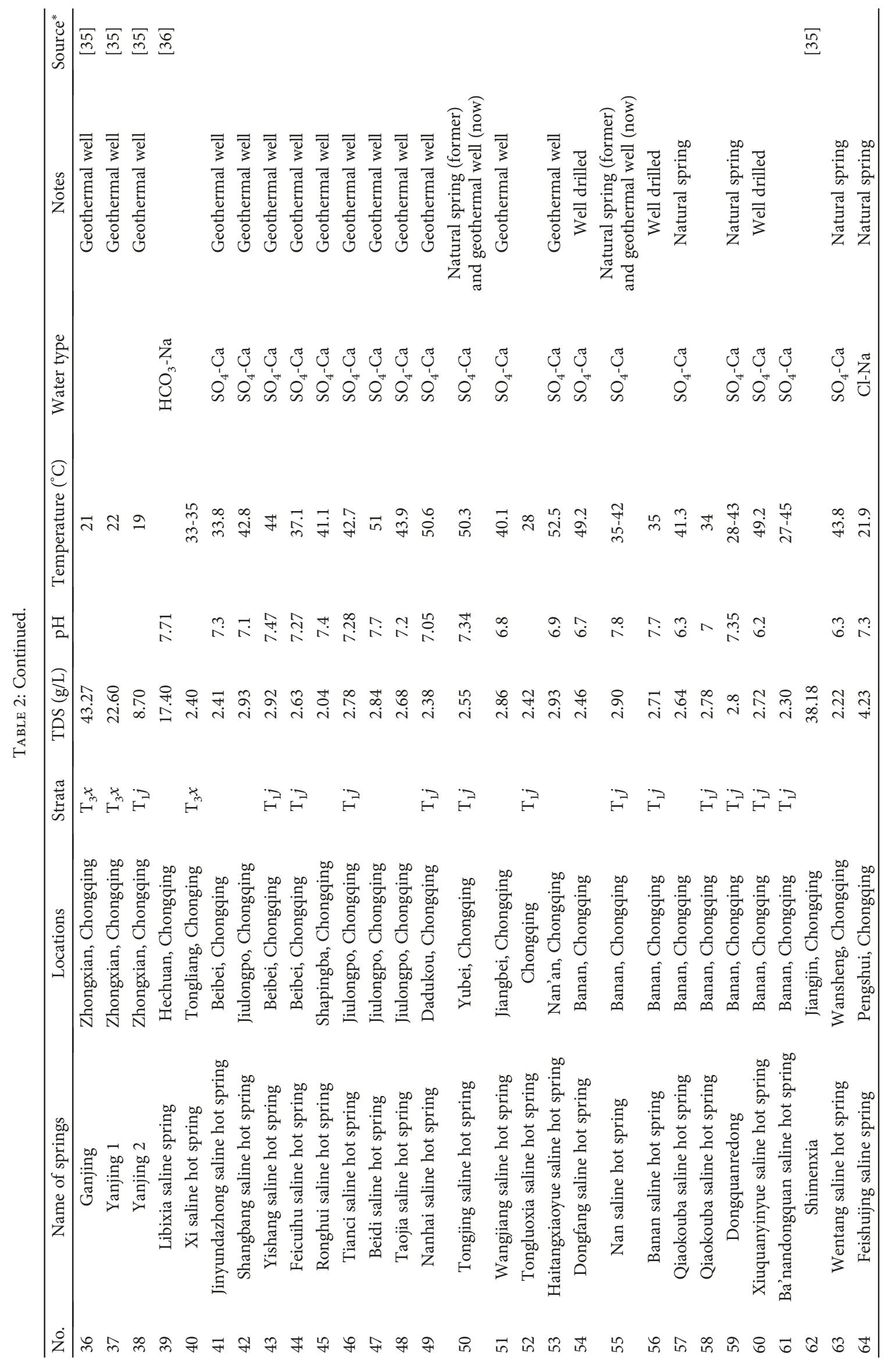


4.1. The Occurrence of the Saline and Salty Springs. The Sichuan Basin has experienced many tectonic events, which are manifested by different types of folds of the sedimentary cap rock and different features of each structural area. The western basin, located to the west of the Longquan Mountains, is steeply dipping fold zones, in which anticlines are of the en echelon shape and NNE and NE trends. The central area of the Sichuan Basin is an uplift zone with gentle folds. The eastern basin is characterized by a series of high steeply dipping anticline belts, which are called barrier parallel folds. The fault structure generally plays an important role in the tectonic contour and lithofacies change in the basin [18]. As shown in Figure 2, the saline and salty springs are mostly located in the margin of the basin where the fractures or fault zones and anticlines developed and are apparently controlled by the tectonic lines. The saline and salty springs and geothermal wells located in the western Sichuan Basin are nos. 1-4 and nos. 5-7 in the southwest, nos. 8-13 in the south, and nos. 14-63 in the east (Figure 2). The strata outcroppings in the basin are mainly Lower Cretaceous Tianmashan Group $\left(\mathrm{K}_{1} t\right)$, upper Jurassic Penlai Group $\left(\mathrm{J}_{3} p\right), \mathrm{T}_{1} j-\mathrm{T}_{2} l$, and $\mathrm{T}_{3} x$ (mostly geothermal wells), and Lower Permian Maokou and Qixia Group $\left(\mathrm{P}_{1} m+q\right)$ (Table 1) which consist of carbonate and clastic rocks. Therefore, the saline and salty springs (wells) could be divided into the following three categories based on the types of occurrence.

4.1.1. Emergence in the Anticline (in River Valleys). Natural springs occur in areas with low elevations in valleys cut by rivers and valley walls in the high-uplift anticlines. Geothermal wells are generally located on the limbs of the anticlines (nos. 8, 15-16, 19, 25, 39-49, 55, and 56), in the plunging ends of the anticlines (nos. 18, 57, 60, and 61), and in the core of the anticlines (nos. 9, 27, 50, 55, 59, and 62) (Figure 2). The reason for this is that vertical fractures and fractures between stratigraphic layers are well developed in the limbs and plunging ends of anticlines, which create porosity and permeable zones that are good for groundwater extraction. In particular, when the angle of the anticlinal limbs is gentler and the slopes of the limbs in the Triassic strata are longer, an artesian aquifer is commonly formed creating an area favorable for groundwater extraction [42]. The hydrochemical types of springs in the anticlines vary depending on the degree of porosity and permeability which results in different rates of alteration of the water [43]. In the area of high-uplift with outcropping and shallow buried anticlines, the saline and salty springs are of $\mathrm{HCO}_{3}$ type and $\mathrm{SO}_{4}$ type (nos. 40$42,50-51,53-58$, and 61). In the high-uplift deep buried anticlines, the springs are mainly of $\mathrm{SO}_{4}$ type and $\mathrm{Cl}$ type (nos. 59, 60), while the springs in the low-uplift deep buried anticline are mainly of $\mathrm{Cl}$ type (nos. 8, 10-12). In the eastern Sichuan Basin, the Jialingiiang River and the Yangtze River deeply cut the anticlines, forming canyons and becoming discharge points for springs, which control the groundwater flow systems [43]. This is a major type of the occurrence of the saline and salty springs in the Sichuan Basin.
4.1.2. Emergence on the Faults or Fault Zones. Geological structures have more influence on springs. Faults or fault zones are generally considered to have greater permeability than fractures or unfractured layered strata [40]. Faults and fracture zones are generally areas of active groundwater flow and storage and groundwater discharge. Fracture zones are associated with faults, which allow deep waters to rise and carry the heat of the deeper crust to the surface in the form of hot springs. The structural fabric in the western Sichuan Basin is mainly NE-SW and NWSE, including deep faults such as thrust faults and basement faults, while the northeastern basin is dominated by the NW-SE structural trends, which springs (nos. 1, 4,6 , and 20) occur.

4.1.3. Emergence in Other Types. There are also other types of spring occurrence. For instance, the spring occurrence can be jointly controlled the anticlines and faults, which combines the above two controls on the occurrence of the springs. Folds and faults that cross each other can form structural fractures that can be enlarged by dissolution or karst processes. Groundwater flows slowly through the formations and finally discharges in the form of springs, such as the saline springs in the northeastern (nos. 21-24) and the western (nos. 2, 3) Sichuan Basin. A special type of springs called an upflow spring (nos. 18, 52) emerges where the groundwater in the $\mathrm{T}_{2} l-\mathrm{T}_{1} j$ thermal reservoir goes upward through the overlying $\mathrm{T}_{3} x$ and $\mathrm{J}_{2} s-\mathrm{J}_{1} z$ and occurs in the sandstone, shale, and other formations in the valley in the form of a saline and salty (hot) springs [29]. Another type of the spring occurs at the contact zone between different types of strata. For example, the spring in the Yong'an Town, near Mianyang, occurs in the unconformable contact zone of the Triassic and Quaternary sediments (since TDS of the spring in the Yong'an is less than $2 \mathrm{~g} / \mathrm{L}$ [34], the data of the spring is not selected in this study).

\subsection{Hydrochemical Characteristics of the Saline and Salty Springs}

4.2.1. Physical and Hydrochemical Parameters of the Saline and Salty Springs. The basic physical and hydrochemical parameters of the saline and salty springs (TDS, $\mathrm{pH}$, and temperature $(\mathrm{T})$ ) in the basin are showed in Table 2. The box plots (Figure 3 ) show the range of ion concentration and the TDS $(\mathrm{g} / \mathrm{L}), \mathrm{pH}$, and $\mathrm{T}\left({ }^{\circ} \mathrm{C}\right)$ of the springs (wells) in the Sichuan Basin using the statistical software SPSS.

(1) The TDS of the saline and salty springs (wells) in the Sichuan Basin range from 2.0 to $82.9 \mathrm{~g} / \mathrm{L}$ with a mean of $10.9 \mathrm{~g} / \mathrm{L}$. The values in the northeastern basin are from 2.4 to $82.9 \mathrm{~g} / \mathrm{L}$ with an average of $18.4 \mathrm{~g} / \mathrm{L}$, which is higher than those of other regions. Some of the saline and salty springs are shown in Figure 4. The average TDS of the water samples (nos. 20, 26, 29 , and 30 ) are $57.2 \mathrm{~g} / \mathrm{L}$ in the northern basin. In addition to no. 17 and no. 62 , the TDS are basically $2-3 \mathrm{~g} / \mathrm{L}$ in the eastern basin in Chongqing. The TDS values in the southern basin range from 2.7 to 

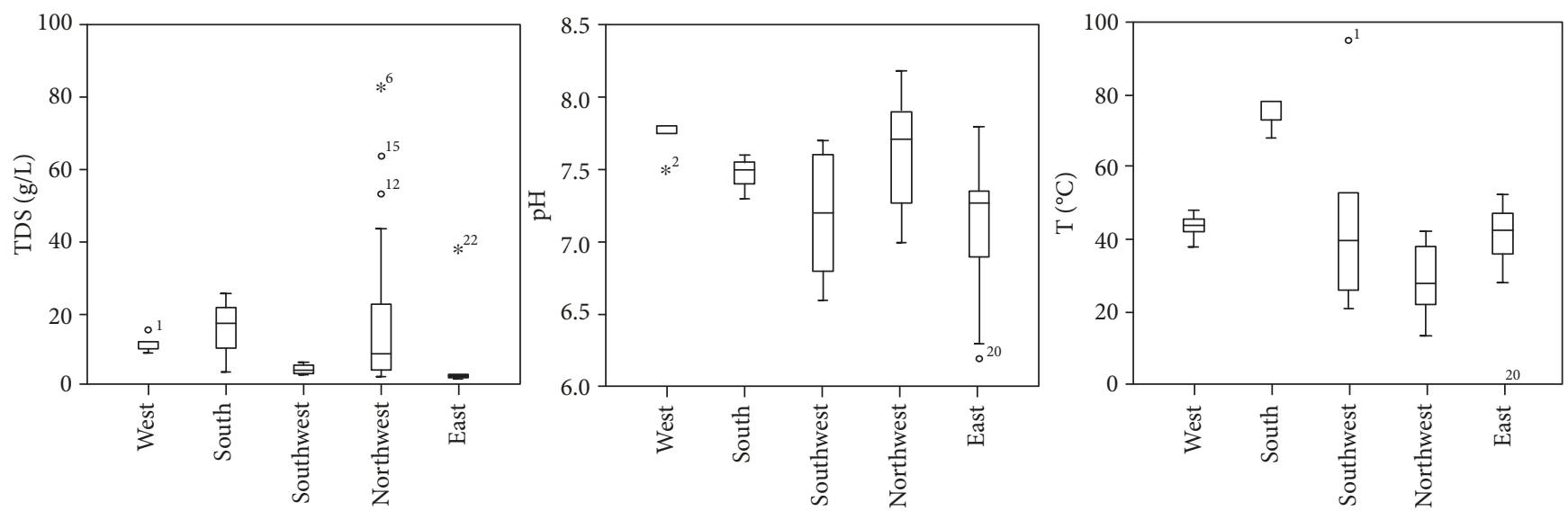

FIgURE 3: Plots of TDS, $\mathrm{pH}$, and temperature $(\mathrm{T})$ of water samples in different areas in the Sichuan Basin.

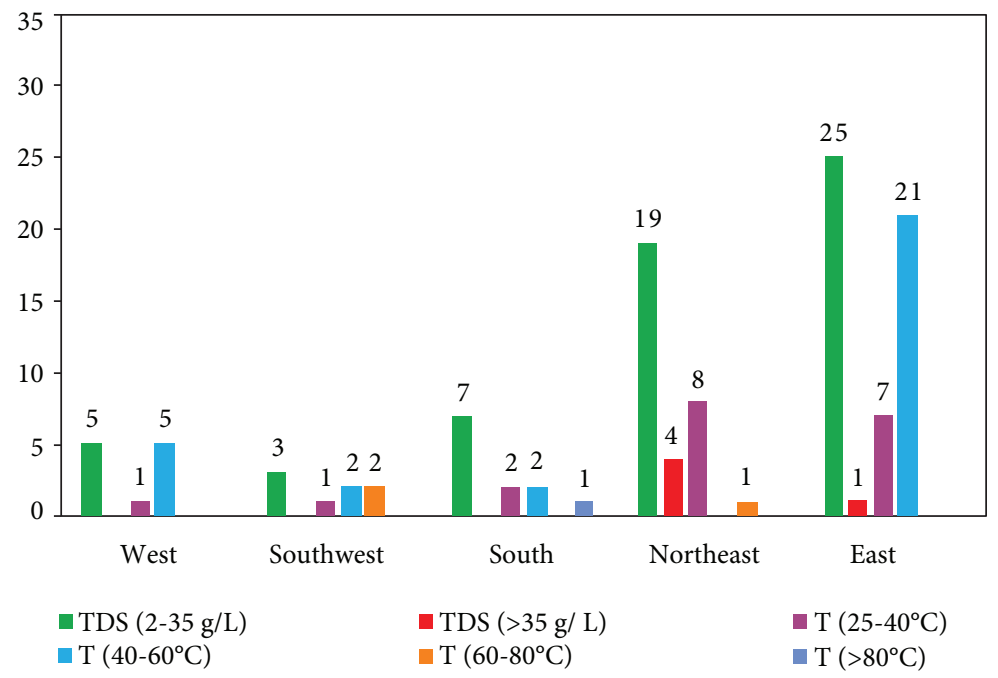

FIgURE 4: TDS and temperature of some of the springs in the Sichuan Basin.

$6.7 \mathrm{~g} / \mathrm{L}$ with an average of $4.2 \mathrm{~g} / \mathrm{L}$ and are lower than those in the western region (Figure 3 ). In general, excluding other factors, TDS are positively correlated with depth $[41,44]$. However, there are some special situations in the basin because of the Mesozoic salt deposits, especially the Triassic salt deposits, where high TDS result from salt dissolution $[17,36]$

(2) The temperature of saline and salty springs in the basin ranges from $19^{\circ} \mathrm{C}$ to $95^{\circ} \mathrm{C}$ with a mean of $40.3^{\circ} \mathrm{C}$. The temperature in the southwest basin is the highest $\left(68-78^{\circ} \mathrm{C}\right)$. The southern basin shows a large degree of variation from 21 to $95^{\circ} \mathrm{C}$. The temperature of the water in the eastern and northeastern basin ranges between 40 and $60^{\circ} \mathrm{C}$ (Figure 3 ). Temperature of the groundwater is generally correlated with the depth of circulation, the exothermic reaction, and the geothermal gradient in the sedimentary basin $[36,45]$. The various temperatures of the saline and salty springs in the basin indicate that the circulation depth of groundwater and the geothermal gradient are different in the different regions, and to a certain degree, it can be explained by burial depth of the aquifer. The $\mathrm{pH}$ values of the saline and salty springs in the basin range from 6.6 to 8.2 with an average of 7.3 , which is in the range of slightly acidic to alkaline water. The $\mathrm{pH}$ values in the northeastern basin vary more widely, ranging from 6.8 to 8.2 , followed by the southern and eastern regions with $\mathrm{pH}$ in the range of 6.8-7.7 and 6.2-7.92, respectively (Figure 3)

(3) The Piper diagram (Figure 5) illustrates the dispersion of the major cations $(\mathrm{Ca}, \mathrm{Mg}, \mathrm{K}$, and $\mathrm{Na}$ ) and anions $\left(\mathrm{HCO}_{3}, \mathrm{Cl}\right.$, and $\left.\mathrm{SO}_{4}\right)$ in the saline and salty springs and indicates the hydrogeochemical facies of the spring water samples. The main hydrochemical types of the saline and salty springs (and geothermal wells) in the Sichuan Basin are different from region to region. The main hydrochemical types of the saline and salty springs in the eastern Sichuan Basin are of $\mathrm{SO}_{4}$-Ca type, the northeast are mainly 


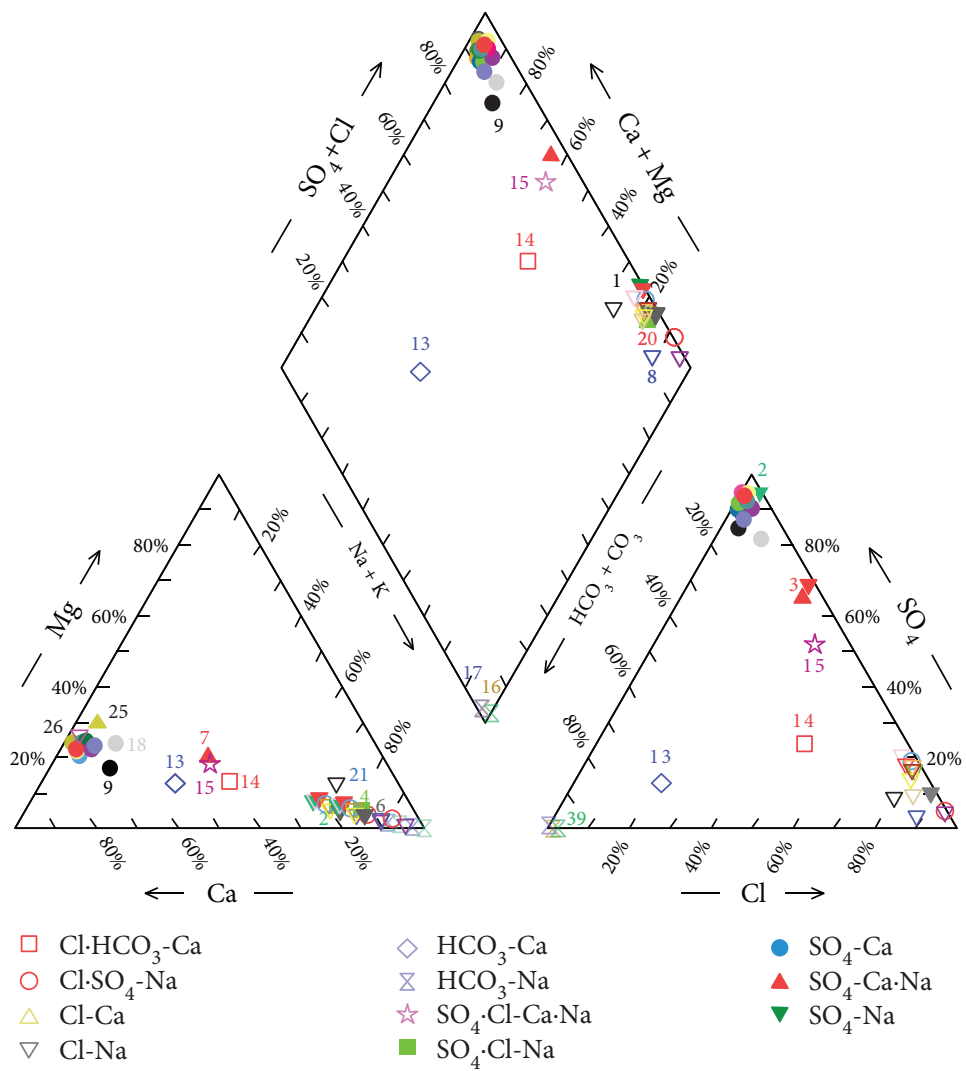

FIGURE 5: Piper diagram showing hydrochemical types of the saline and salty springs in the Sichuan Basin.

of $\mathrm{HCO}_{3}-\mathrm{Na}, \mathrm{Cl}-\mathrm{Na}$, and $\mathrm{Cl} \cdot \mathrm{SO}_{4}-\mathrm{Na}$ type, the west are mainly of $\mathrm{SO}_{4}-\mathrm{Na}$ type, and the southwest are mainly of $\mathrm{SO}_{4}$-Ca.Na type (Table 2). Lower salinity $(2 \mathrm{~g} / \mathrm{L}<\mathrm{TDS}<3 \mathrm{~g} / \mathrm{L})$ of the saline springs (and geothermal wells) was accompanied by predominantly $\mathrm{SO}_{4}$-Ca type except for the samples of no. 13 $\left(\mathrm{HCO}_{3}-\mathrm{Ca}\right)$, no. $14\left(\mathrm{Cl} \cdot \mathrm{HCO}_{3}-\mathrm{Ca}\right)$, no. $15\left(\mathrm{SO}_{4} \cdot \mathrm{Cl}-\right.$ $\mathrm{Ca} \cdot \mathrm{Na})$, and no. $16\left(\mathrm{HCO}_{3}-\mathrm{Na}\right)$. Higher salinization (TDS $>3 \mathrm{~g} / \mathrm{L}$ ) of the saline and salty springs (and geothermal wells) was predominated due to anions of $\mathrm{SO}_{4}$ and $\mathrm{Cl}$ and cation of $\mathrm{Na}$. Generally, $\mathrm{HCO}_{3}-$ $\mathrm{Ca}$ type water most likely represents groundwater flow along relatively short, lateral flow paths that originate in high-rate recharge areas or dominated by dissolution of carbonate minerals [46, 47]. Cl-Na type water most likely represents the early stage of groundwater evolution [41] or dissolution of salt rocks in the water-rock interaction processes [47]. $\mathrm{SO}_{4}$-Ca type water mostly is caused by the dissolution of the evaporite rocks [36]. $\mathrm{SO}_{4}$-Na type is probably controlled by the precipitation of the carbonate minerals (such as calcite and dolomite) in the basin [23]. Cl-Na and $\mathrm{SO}_{4}$-Ca type waters are caused by the dissolution of halite and gypsum based on the hydrogeology in the Sichuan Basin

4.2.2. Characteristics of Main Ions of the Saline and Salty Springs. In sedimentary basins, hydrochemical compositions of groundwater are mainly affected by lithology, hydrochemical processes, and residence time [1, 39]. Correlation matrices have been widely used as a useful statistical method for detecting the relationships among hydrochemical species [22].

Tables 3, 4, and 5 show the results of the correlation analyses of the physical and chemical parameters in different regions of the Sichuan Basin. The correlations between TDS and ion concentrations in the different regions are somewhat different. The TDS in the western basin are correlated with the concentrations of $\mathrm{K}, \mathrm{Na}, \mathrm{Ca}, \mathrm{Mg}$, and $\mathrm{Cl}$; the correlation coefficients are $0.81,0.95,0.86,0.73$, and 0.86 , respectively (Table 3). In the northeastern basin, the TDS of the springs are correlated with the concentrations of $\mathrm{K}, \mathrm{Na}$, and $\mathrm{Cl}$; the correlation coefficients are $0.79,0.78$, and 0.86 , respectively (Table 4). The TDS in the eastern basin are related to concentrations of $\mathrm{K}, \mathrm{Na}$, and $\mathrm{Cl}$, and the correlation coefficients are $0.67,0.82$, and 0.81 , respectively (Table 5 ). Those correlation coefficients between TDS and major ions imply that TDS have a significant effect on the chemical properties of the saline and salty springs. Negative correlations are observed for the concentrations of $\mathrm{SO}_{4}$ with the concentrations of $\mathrm{K}, \mathrm{Na}$, and $\mathrm{Cl}$ in the northeastern basin; their correlation coefficients are $-0.71,-0.86$, and -0.86 , respectively. The correlation between $\mathrm{Na}$ and $\mathrm{Cl}$ is positive with a correlation of $0.95,1$, and 1 , respectively (Tables 3,4 , and 5), indicating a provenance involving halite $(\mathrm{NaCl})$ dissolution $[17,48]$. The good correlation between $\mathrm{Ca}$ and $\mathrm{SO}_{4}$ (coefficients of 0.9 and 0.89 , respectively) (Tables 4 and 5) in the eastern and northeastern Sichuan Basin implies that they are derived 
TABLE 3: Correlation matrix of physical and chemical parameters of the saline and salty springs (well) in western Sichuan Basin.

\begin{tabular}{|c|c|c|c|c|c|c|c|c|c|c|}
\hline Parameter & TDS & $\mathrm{pH}$ & $\mathrm{T}$ & $\mathrm{K}$ & $\mathrm{Na}$ & $\mathrm{Ca}$ & $\mathrm{Mg}$ & $\mathrm{Cl}$ & $\mathrm{SO}_{4}$ & $\mathrm{HCO}_{3}$ \\
\hline TDS & 1.00 & 0.28 & 0.37 & $0.81^{* *}$ & $0.95^{* *}$ & $0.86^{* *}$ & $0.73^{* *}$ & $0.86^{* *}$ & 0.34 & 0.28 \\
\hline $\mathrm{pH}$ & & 1.00 & -0.03 & 0.12 & 0.12 & 0.24 & 0.41 & 0.00 & 0.45 & 0.21 \\
\hline $\mathrm{T}$ & & & 1.00 & $0.56^{*}$ & 0.49 & 0.33 & 0.16 & $0.55^{*}$ & -0.17 & 0.03 \\
\hline K & & & & 1.00 & $0.88^{* *}$ & $0.81^{* *}$ & 0.52 & $0.93^{* *}$ & -0.04 & 0.22 \\
\hline $\mathrm{Na}$ & & & & & 1.00 & $0.87^{* *}$ & $0.64^{*}$ & $0.95^{* *}$ & 0.24 & 0.20 \\
\hline $\mathrm{Ca}$ & & & & & & 1.00 & $0.79^{* *}$ & $0.83^{* *}$ & 0.30 & 0.26 \\
\hline $\mathrm{Mg}$ & & & & & & & 1.00 & $0.60^{* *}$ & 0.26 & $0.69^{* *}$ \\
\hline $\mathrm{Cl}$ & & & & & & & & 1.00 & -0.08 & 0.32 \\
\hline $\mathrm{SO}_{4}$ & & & & & & & & & 1.00 & -0.32 \\
\hline $\mathrm{HCO}_{3}$ & & & & & & & & & & 1.00 \\
\hline
\end{tabular}

TABLE 4: Correlation matrix of physical and chemical parameters of the saline and salty springs (well) in northeastern Sichuan Basin.

\begin{tabular}{|c|c|c|c|c|c|c|c|c|c|c|}
\hline Parameter & TDS & $\mathrm{pH}$ & $\mathrm{T}$ & $\mathrm{K}$ & $\mathrm{Na}$ & $\mathrm{Ca}$ & $\mathrm{Mg}$ & $\mathrm{Cl}$ & $\mathrm{SO}_{4}$ & $\mathrm{HCO}_{3}$ \\
\hline TDS & 1.00 & -0.07 & -0.45 & $0.79^{* *}$ & $0.78^{* *}$ & $0.51^{*}$ & 0.18 & $0.78^{*}$ & 0.53 & -0.11 \\
\hline $\mathrm{pH}$ & & 1.00 & 0.26 & 0.38 & 0.44 & 0.24 & 0.25 & 0.44 & -0.02 & -0.45 \\
\hline $\mathrm{T}$ & & & 1.00 & -0.80 & -0.78 & -0.71 & -0.72 & -0.78 & -0.45 & 0.13 \\
\hline K & & & & 1.00 & $0.89^{* *}$ & $0.76^{* *}$ & 0.06 & $0.90^{* *}$ & $0.61^{*}$ & 0.00 \\
\hline $\mathrm{Na}$ & & & & & 1.00 & $0.82^{* *}$ & -0.19 & $1.00^{* *}$ & $0.56^{*}$ & -0.09 \\
\hline $\mathrm{Ca}$ & & & & & & 1.00 & -0.37 & $0.82^{* *}$ & $0.89^{* *}$ & -0.19 \\
\hline $\mathrm{Mg}$ & & & & & & & 1.00 & -0.19 & $0.88^{* *}$ & -0.20 \\
\hline $\mathrm{Cl}$ & & & & & & & & 1.00 & $0.60^{*}$ & -0.09 \\
\hline $\mathrm{SO}_{4}$ & & & & & & & & & 1.00 & -0.22 \\
\hline $\mathrm{HCO}_{3}$ & & & & & & & & & & 1.00 \\
\hline
\end{tabular}

TABLE 5: Correlation matrix of physical and chemical parameters of the saline and salty springs (well) in eastern Sichuan Basin.

\begin{tabular}{|c|c|c|c|c|c|c|c|c|c|c|}
\hline Parameter & TDS & $\mathrm{pH}$ & $\mathrm{T}$ & $\mathrm{K}$ & $\mathrm{Na}$ & $\mathrm{Ca}$ & $\mathrm{Mg}$ & $\mathrm{Cl}$ & $\mathrm{SO}_{4}$ & $\mathrm{HCO}_{3}$ \\
\hline TDS & 1.00 & 0.20 & -0.15 & $0.67^{* *}$ & $0.82^{* *}$ & -0.35 & -0.31 & $0.81^{* *}$ & $-0.46^{*}$ & $0.49^{*}$ \\
\hline $\mathrm{pH}$ & & 1.00 & -0.40 & 0.32 & 0.11 & 0.01 & 0.02 & 0.13 & -0.11 & -0.05 \\
\hline $\mathrm{T}$ & & & 1.00 & -0.14 & -0.27 & 0.20 & 0.13 & -0.25 & 0.30 & -0.23 \\
\hline K & & & & 1.00 & $0.82^{* *}$ & $-0.48^{*}$ & $-0.53^{*}$ & $0.82^{* *}$ & $-0.71^{* *}$ & $0.59^{* *}$ \\
\hline $\mathrm{Na}$ & & & & & 1.00 & $-0.73^{* *}$ & $-0.71^{* *}$ & $1.00^{* *}$ & $-0.86^{* *}$ & 0.62 \\
\hline $\mathrm{Ca}$ & & & & & & 1.00 & 0.97 & -0.74 & $0.90^{* *}$ & -0.54 \\
\hline $\mathrm{Mg}$ & & & & & & & 1.00 & -0.72 & $0.87^{* *}$ & -0.47 \\
\hline $\mathrm{Cl}$ & & & & & & & & 1.00 & $-0.86^{* *}$ & $0.63^{* *}$ \\
\hline $\mathrm{SO}_{4}$ & & & & & & & & & 1.00 & $-0.63^{* *}$ \\
\hline $\mathrm{HCO}_{3}$ & & & & & & & & & & 1.00 \\
\hline
\end{tabular}

${ }^{*}$ Correlation is significant at the 0.05 level (2-tailed). ${ }^{* *}$ Correlation is significant at the 0.01 level (2-tailed).

from gypsum or anhydrite dissolution [36]. The correlation coefficients of the concentration $\mathrm{HCO}_{3}$ with $\mathrm{Ca}$ and $\mathrm{Mg}$ are low, and $\mathrm{HCO}_{3}$ concentrations are much lower than those of $\mathrm{SO}_{4}$. This can be possibly explained by the common ion effect as a result of the incongruent dissolution of gypsum or anhydrite leading to reduction in the solubility of $\mathrm{CaCO}_{3}$ and $\mathrm{CaMg}\left(\mathrm{CO}_{3}\right)_{2}$ precipitation. The correlation coefficient for $\mathrm{Mg}$ and $\mathrm{HCO}_{3}$ is 0.69 in the western basin, which indicates that the high $\mathrm{Mg}$ contents are derived from the dissolution of dolomite. The correlation coefficients between $\mathrm{Mg}$ 
and $\mathrm{SO}_{4}$ in the eastern and northeastern Sichuan Basin are 0.87 and 0.88 , respectively, indicating that the source of $\mathrm{Mg}$ is the dissolution of magnesium sulfate minerals.

Cretaceous strata and sporadic Triassic and Permian strata are present in the western. These strata are composed of conglomerate, sandstone, marl, and gypsum or anhydrite layers or lenses, which results in $\mathrm{SO}_{4}$ type water. In the southern basin, there is a small area with thick limestone, dolomite, and halite formations (247-673 m) [18], leading to Cl-Na and $\mathrm{HCO}_{3}$ type water. The eastern and northeastern basins consist of mainly evaporative type formations containing halite, gypsum or anhydrite, and magnesium sulfate. The formations of $\mathrm{T}_{1} j^{1}, \mathrm{~T}_{1} j^{3}, \mathrm{~T}_{1} j^{5}-\mathrm{T}_{2} l^{1}, \mathrm{~T}_{2} l^{3}$, and $\mathrm{T}_{2} l^{4}$ are mainly saltbearing formations in the Sichuan Basin, composed of marine carbonate (limestone and dolomite) interbedded with evaporites (gypsum and halite), which can explain the high correlations between $\mathrm{SO}_{4}$ and $\mathrm{Ca}$ and between $\mathrm{Na}$ and $\mathrm{Cl}$.

\section{Formation of the Saline and Salty Springs}

The formation of the saline and salty springs undergoes infiltration recharge, groundwater circulation, and finally discharge at a suitable topographic point, which describes the flow path of the springs in a natural environment.

5.1. Recharge Area. The mountainous areas that surround around the Sichuan Basin, namely, the marginal zone, and long and narrow anticlines in the eastern basin where carbonate rocks crop out, are the main recharge areas of the groundwater [49]. This area includes fault zones, fold belts, and areas of low mountains. The original primary (matrix) permeability of the carbonate region is low but there is a higher secondary porosity (fractures), especially in the core of anticlines, which is further enhanced by the effects of carbonate dissolution to provide good conduits for the infiltration precipitation $[34,50,51]$. For the geothermal wells, the relative elevation (1900-2500 m) difference between the recharge area and the thermal reservoir creates hydrostatic pressure [18], which causes the groundwater to undergo deep circulation. The deeply circulating groundwater becomes heated as it flows through the reservoir. The groundwater tapped by a drilled well has high artesian pressure, sufficient recharge, and stable well discharge. For example, the yield of the geothermal well (no. 7) is up to $7000 \mathrm{~m}^{3} / \mathrm{d}$ and the head pressure of the well is up to $2.5 \mathrm{MPa}$ [34].

5.2. Groundwater Circulation Systems in the Sichuan Basin. Groundwater mineralization is strongly conditioned by the nature of the bedrock, but also conditioned by the distance and depth of groundwater flow, and in a groundwater system $[1,52,53]$. To a large extent, TDS, temperature, and hydrochemical types of the springs can reflect the circulation depth of groundwater. The saline and salty springs in the Sichuan Basin show a large range of temperature and TDS, which indicate that the springs underwent different depths of circulation and residence time. The higher the temperature and the deeper the circulation, the longer the groundwater residence time is $[26,54,55]$. There are no magmatic rocks in the Sichuan Basin; thus, the temperatures of saline and salty springs are mainly due to the geothermal gradient that is in a geothermal gradient is in a range of $2.4-3.5^{\circ} \mathrm{C} / 100 \mathrm{~m}$ from the gentle fold zones in the central Sichuan Basin to the steeply dipping fold zones with low topography in the southwestern Sichuan Basin [55]. The temperatures of the saline and salty springs (wells) range from $39^{\circ} \mathrm{C}$ (no. 3) to $95^{\circ} \mathrm{C}$ (no. 8). The temperature of the geothermal well (no. 8) in the Xiaoguzhen in the Maliuchang anticline, which is adjacent to the tectonic zone, where the geothermal gradient exceeds $3.5^{\circ} \mathrm{C} / 100 \mathrm{~m}$, reaches $95^{\circ} \mathrm{C}$ (no. 8) [18]. The geothermal gradient of the high steeply dipping anticline belts in the eastern basin and the low-flat folds in the northern Sichuan decreases to about $2.0^{\circ} \mathrm{C} / 100 \mathrm{~m}$, where the average temperature of saline and salty springs (wells) (nos. 39-63) is $42^{\circ} \mathrm{C}$. The geothermal gradient in the edge of the northeastern Sichuan Basin is as low as $1.6^{\circ} \mathrm{C} / 100 \mathrm{~m}$ [55]. The temperature of the salty well (no. 20) located in this area is as low as $13.4^{\circ} \mathrm{C}$. The fractures are well developed in the mountains in the cores of anticlines in the northeastern basin and groundwater rapidly infiltrates downward, causing a further reduction in the local geothermal gradient, which is much lower than the average value of the basin. These observations indicate that temperature of the saline and salty springs is related with geothermal gradient, which corresponds to geologic structure.

Different circulation systems in the Sichuan Basin are responsible for different hydrochemical characteristics of springs and geothermal wells. The local groundwater flow system has a shallow burial depth. Springs with low TDS and temperature are present in this zone and are commonly called shallow-cycle springs [56]. The TDS of the springs are normally less than $2 \mathrm{~g} / \mathrm{L}$ with $\mathrm{HCO}_{3}$-Ca type water, which mainly occurs at the outcrop of Triassic carbonate, especially in the cores of the anticlines with a rapid recharge rate. The lower limit of the groundwater circulation depth of a shallow-cycle spring is lower than that of the local discharge basis (local river), such as the flow line A in Figure 6. The regional flow system has a deep burial depth, and the springs are mostly of Cl-Na type with the higher TDS and temperature called deep-cycle springs [57], such as flow line B in Figure 6. The final discharge point of the regional flow in the Sichuan Basin is generally controlled by the Yangtze River (nos. 13, 51, 52, and 53) and its branches and the Jialingjiang River (nos. 41, 42). It is worth noting that the brine in the western basin is stagnant and the brine in the eastern syncline zones is confined and does not participate in modern water cycles. The main hydrochemical types of the brine water are $\mathrm{Cl}-\mathrm{Na}$ and $\mathrm{Cl}-\mathrm{Na} \cdot \mathrm{Ca}$ type [58, 59] (Figure 7). The saline and salty springs have their own circulation systems, which are characterized by different TDS and temperatures. For examples, the circulation depth of saline and salty springs (wells) in the eastern Sichuan Basin (Chongqing) can reach an average of $2150 \mathrm{~m}$ with a mean TDS of $2.6 \mathrm{~g} / \mathrm{L}$ [36], the circulation depth of the no.18 salty hot spring in the northeast reaches $1000 \mathrm{~m}$ [59] with a TDS of $2.8 \mathrm{~g} / \mathrm{L}$, and the circulation depth of the geothermal well (no. 4) in western basins can reach 1800-2500 $\mathrm{m}$ [60] with TDS of $10 \mathrm{~g} / \mathrm{L}$. 


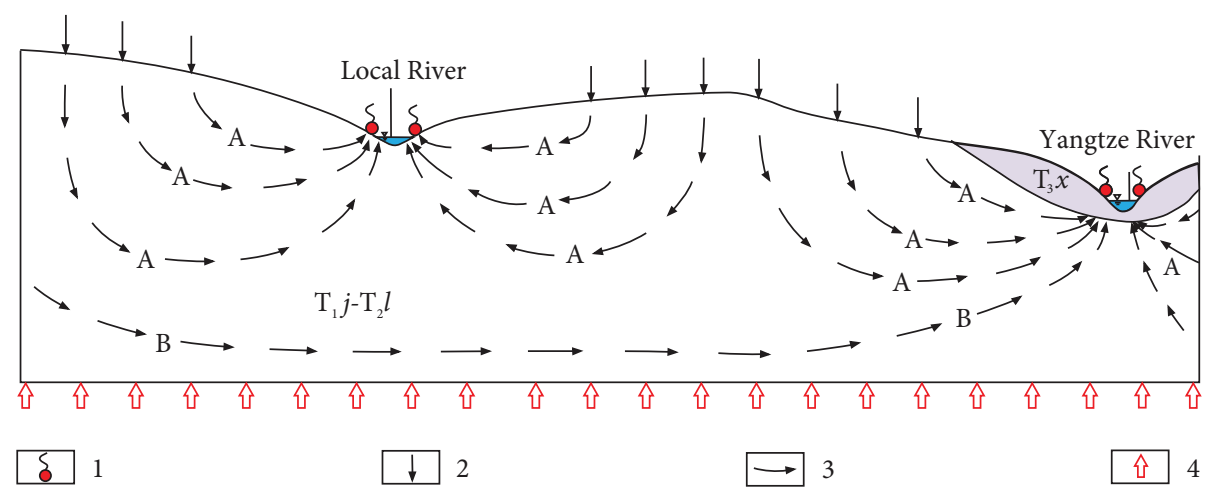

Figure 6: Conceptual profile of circulation patterns of saline and salty springs along the flank of the anticline in the Sichuan Basin. 1: saline or salty spring; 2: precipitation infiltration; 3: groundwater flow direction; 4 : heat flow; $\mathrm{T}_{3} x$ : Upper Triassic Xujiahe Group; $\mathrm{T}_{2} l:$ Middle Triassic Leokoupo Group; $\mathrm{T}_{1}$; : Lower Triassic Jialingjiang Group; A: local groundwater flow system; B: regional groundwater flow system.

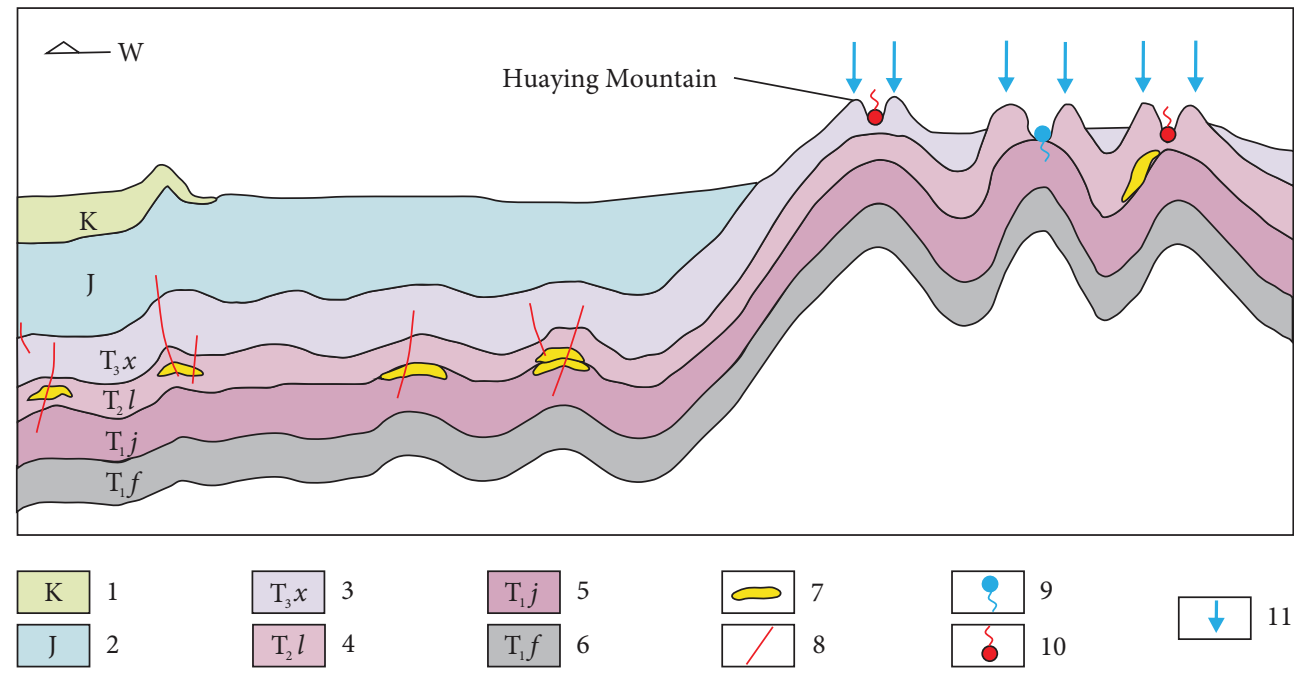

FIGURE 7: Schematic nearly east-west profile showing the saline and salty springs in the central and eastern Sichuan Basin (modified from Xun et al. [57]). 1: Cretaceous glutenite and mudstone; 2: Jurassic sandstone and mudstone; 3: Upper Triassic shale, mudstone interbedded with siltstone, and sandstone; 4: Middle Triassic carbonate interbedded with evaporites; 5: Lower Triassic carbonate interbedded with evaporites; 6: gypsum (anhydrite) and halite; 7: fault; 8: cold spring; 9: saline or salty spring; 10: precipitation.

5.3. Conceptual Models of the Circulation of the Saline and Salty Springs. The following two conceptual models are proposed for the formation of the saline and salty springs in the Sichuan Basin. The high TDS are attributed to the $\mathrm{T}_{1} j-\mathrm{T}_{2} l$ salt-bearing formations (mainly halite) and also to a deeper depth of groundwater flows within the systems.

The main hydrogeological features of the saline and salty springs in the Sichuan Basin are summarized in Figure 7. To a large extent, the model of groundwater circulation is affected by the hydrodynamic condition [61]. Cretaceous and Jurassic formations mainly crop out in the area of the western Huaying Mountain Fold Belt. Triassic formations are distributed sporadically in this area. The permeability of the rock in this area is low, and the groundwater circulation is shallow with limited flow on a regional scale. However, deep-circulation groundwater can be formed in faults and fold zones. Groundwater that flows to the deep zone is continuously heated by heat flow with incongruent dissolution of evaporites and carbonate rocks. This groundwater is often discharged in the form of saline springs in river valley or in lower-elevation areas, forming water of $\mathrm{SO}_{4}-\mathrm{Na}, \mathrm{SO}_{4} \cdot \mathrm{Cl}-\mathrm{Na}$ types (nos. 2, 3, and 4) and $\mathrm{Cl}-\mathrm{Na}$ type (no. 1) with a range of $9-15 \mathrm{~g} / \mathrm{L}$ in TDS. Because of denudation, the anticline core of the Weiyuan-Zigong District exposes $\mathrm{T}_{1} j$ formation, which generally formed groundwater with water of $\mathrm{SO}_{4}$-Ca type from dissolution (no. 9). The brines in the $\mathrm{T}_{1} j$ and $\mathrm{T}_{2} l$ formations in the central and western basin are still in a deeply buried and stagnant state, and they have not yet been affected by modern water circulation. Except for the denudation of $\mathrm{T}_{1} j$ and $\mathrm{T}_{2} l$ formations in the Indosinian in the Luzhou area, the Triassic formation buried deeply in the southern basin, formed sedimentary connate brines of $\mathrm{Cl}-\mathrm{Na}$ and $\mathrm{Cl}-\mathrm{Na} \cdot \mathrm{Ca}$ type. The eastern and northeastern Sichuan Basin is mainly controlled by anticline structures, which are in a near-NS trending direction. The core of anticline is cut by rivers where the Triassic strata crop out extensively widely and receive infiltration from precipitation in recharge areas. The precipitation percolates to the two limbs 
of the anticlines with shallow or deep circulation (local or regional groundwater flow system). The water incongruently dissolves carbonates and evaporites simultaneously (including anhydrite and halite) in the $\mathrm{T}_{1} j$ and $\mathrm{T}_{2} l$ rocks during its transport. The discharge areas are often in the middle of the anticline or in the low-lying areas of the limbs or plunging ends where carbonate rocks crop out, or the low-lying areas of noncarbonate rocks in the river valleys, which lead to natural emergence of the saline and salty springs with different temperatures. The saline and salty springs are mainly of $\mathrm{HCO}_{3}$ - $\mathrm{Na}$ type (nos. 16, 17), $\mathrm{SO}_{4}$-Ca type (nos. 18, 4163), $\mathrm{Cl} \cdot \mathrm{SO}_{4}-\mathrm{Ca} \cdot \mathrm{Na}$ type (no. 15), Cl-Na type (nos. 19, 22, 23, and 26), and Cl-Ca type (no. 55) in the anticlines, which belong to the active alternation area of water circulation (Figure 6). When the brines are in deeply buried in the Triassic strata in the synclines, they are of $\mathrm{Cl}-\mathrm{Na}$ and $\mathrm{Cl}-\mathrm{Na} \cdot \mathrm{Ca}$ type $[57,62]$.

\section{Conclusions}

The main objective of this work was to understand the occurrence and hydrochemical characteristics of the saline and salty springs in the Sichuan Basin. The Middle-Lower Triassic $\left(\mathrm{T}_{1} j-\mathrm{T}_{2} l\right)$ is the most important salt-bearing formation composed of marine carbonate and evaporite rocks. The outcrop areas of the Triassic strata provide good recharge areas that make precipitation infiltrate into ground for circulation.

The saline and salty springs in the Sichuan Basin occur in river valleys, the cores and plunging ends of anticlines, fault zones, and low valleys with noncarbonate rocks. The temperature of the saline and salty springs (geothermal wells) is controlled by the geothermal gradients and depth of groundwater circulation. For example, the temperature of the Xiaogu saline spring (no. 8) in the Maliuchang anticline in the western basin is as high as $95^{\circ} \mathrm{C}$ with the geothermal gradient of $3.5^{\circ} \mathrm{C} / 100 \mathrm{~m}$. The higher TDS of the springs are controlled by salt-bearing rocks of the Low and Middle Triassic and Permian. Multiple hydrochemical water types are present in the basin, including $\mathrm{Cl}-\mathrm{Na}$ type in the northeastern and southwestern basins, $\mathrm{SO}_{4}$ - $\mathrm{Ca}$ type in the eastern basin, and $\mathrm{HCO}_{3}-\mathrm{Na}, \mathrm{Cl} \cdot \mathrm{SO}_{4}-\mathrm{Na}, \mathrm{SO}_{4}-\mathrm{Na}$, and $\mathrm{SO}_{4}$-Ca.Na type in the western and northeastern basins.

The major ions of saline and salty springs in the Sichuan Basin are from incongruent dissolution of halite, gypsum, dolomite, and magnesium sulfate minerals in the Cretaceous, Triassic, and Permian strata (conglomerate, sandstone, marlstone, and gypsum or anhydrite layers or lenses) in the western basin, and the outcropping marine carbonate (limestone and dolomite) interbedded with evaporites (gypsum and halite) in the eastern basin. The marginal zone and long and narrow anticlines in the eastern basin where carbonate rocks crop out are the main recharge areas of the groundwater. The depth of groundwater circulation of the saline and salty springs in the basin ranges from 1800 to $2500 \mathrm{~m}$. Most of the saline and salty springs and discharge points of the local groundwater flow system are controlled by the local rivers, and the discharge of the regional groundwater flow systems is controlled by the Yangtze River (nos. 13, 51, 52, and 53) and its main branches, such as the Jialingjiang River (nos. 41, 42).

The conceptual models of circulation of the saline and salty springs indicate that meteoric water infiltrates in the outcropping carbonate rocks with fractures in the eastern basin and in basin margin, percolates to the limbs of the anticline or deep aquifers connected by the faults, dissolves carbonates, and evaporates (including anhydrite and halite) in the $\mathrm{T}_{1} j$ and $\mathrm{T}_{2} l$ strata during its transport. The groundwater is continuously heated by geothermal heat flow from below. The discharge areas are often in the middle of the anticline or in the low-lying areas of the limbs or plunging ends where carbonate rocks crop out, the low-lying areas of the noncarbonate rocks in river valleys, and the valley where groundwater goes upward through the noncarbonate rocks of the overlying $\mathrm{T}_{3} x$ and $\mathrm{J}_{2} s-\mathrm{J}_{1} z$ aquitards with the active alternation of water circulation. Subsurface brines are deeply buried in the Triassic strata in the synclines in the eastern basin and in the central basin, which have not been affected by the modern water circulation.

\section{Data Availability}

The spring sample data used to support the findings of this study are included within the article.

\section{Conflicts of Interest}

The authors declare that they have no conflicts of interest.

\section{Acknowledgments}

This work was supported by the National Natural Science Foundation of China (41572223), the Fundamental Research Funds for the Central Universities of China (2652016098), the National Key Project of Foundational Research and Development of China (973 Project) (2011CB403005), and the Project from Chinese Geological Survey (1212010011803). The authors want to thank M.S. Qin Cao, Yongshuai Zhang, Fei Yin, Xiaowei Shen, Xinyun Wang, $\mathrm{Na} \mathrm{Li}$, and Yanqiu Xu for their help in the field work. The authors would like to thank Dr. John R. Jansen from Collier Consulting in the USA for editing this paper for English grammar.

\section{References}

[1] J. Tóth, "Groundwater as a geologic agent: an overview of the causes, processes, and manifestations," Hydrogeology Journal, vol. 7, no. 1, pp. 1-14, 1999.

[2] N. Goldscheider, J. Madl-Szonyi, A. Eross, and E. Schill, "Review: thermal water resources in carbonate rock aquifers," Hydrogeology Journal, vol. 18, no. 6, pp. 1303-1318, 2010.

[3] L. P. Knauth, "Origin and mixing history of brines, Palo Duro Basin, Texas, USA,” Applied Geochemistry, vol. 3, no. 5, pp. 455-474, 1988.

[4] L. M. Walter, A. M. Stueber, and T. J. Huston, "Br-Cl-Na systematics in Illinois Basin fluids; constraints on fluid origin and evolution," Geology, vol. 18, no. 4, pp. 315-318, 1990. 
[5] D. L. Pinti, C. Béland-Otis, A. Tremblay et al., "Fossil brines preserved in the St-Lawrence Lowlands, Québec, Canada as revealed by their chemistry and noble gas isotopes," Geochimica et Cosmochimica Acta, vol. 75, no. 15, pp. 4228-4243, 2011.

[6] R. Bagheri, A. Nadri, E. Raeisi, G. A. Kazemi, H. G. M. Eggenkamp, and A. Montaseri, "Origin of brine in the Kangan gasfield: isotopic and hydrogeochemical approaches," Environmental Earth Sciences, vol. 72, no. 4, pp. 10551072, 2014.

[7] X. Zhou, C. Jiang, J. Zhao, Q. Cao, J. Han, and X. Wang, "Occurrence and resource evaluation of the subsurface high$\mathrm{K}$ brines in the Pingluoba brine-bearing structure in western Sichuan Basin," Environmental Earth Sciences, vol. 73, no. 12, pp. 8565-8574, 2015.

[8] D. J. Bottomley, A. Katz, L. H. Chan et al., "The origin and evolution of Canadian shield brines: evaporation or freezing of seawater? New lithium isotope and geochemical evidence from the slave craton," Chemical Geology, vol. 155, no. 3-4, pp. 295320, 1999.

[9] P. E. Dresel and A. W. Rose, Chemistry and Origin of Oil and Gas Well Brines in Western Pennsylvania, Pennsylvania Geological Survey, Open-File Oil and Gas Report, 2010.

[10] A. Vengosh, A. R. Chivas, A. Starinsky, Y. Kolodny, Z. Baozhen, and Z. Pengxi, "Chemical and boron isotope compositions of nonmarine brines from the Qaidam Basin, Qinghai, China," Chemical Geology, vol. 120, no. 1-2, pp. 135-154, 1995.

[11] D. J. Toth and B. G. Katz, "Mixing of shallow and deep groundwater as indicated by the chemistry and age of karstic springs," Hydrogeology Journal, vol. 14, no. 6, pp. 1060-1080, 2006.

[12] D. S. Glazier, “Springs," Encyclopedia of Inland Waters, vol. 32, no. 11, pp. 734-755, 2009.

[13] K. Bryan, "Classification of springs," Journal of Geology, vol. 27, no. 7, pp. 522-561, 1919.

[14] C. Alfaro and M. Wallace, "Origin and classification of springs and historical review with current applications," Environmental Geology, vol. 24, no. 2, pp. 112-124, 1994.

[15] P. K. Naik, A. K. Awasthi, and P. C. Mohan, "Springs in a headwater basin in the Deccan Trap country of the Western Ghats, India," Hydrogeology Journal, vol. 10, no. 5, pp. 553$565,2002$.

[16] X. Zhou, X. Jin, S. Liang, Y. Shen, and H. Zhang, Special Topics on Groundwater Science, Geological Publishing House, Beijing, 2010.

[17] J. Guo, X. Zhou, L. Wang et al., "Hydrogeochemical characteristics and sources of salinity of the springs near Wenquanzhen in the eastern Sichuan Basin, China," Hydrogeology Journal, vol. 26, no. 4, pp. 1137-1151, 2018.

[18] X. L. Cui, The Genetic Model of Hot Spring in Western Sichuan Basin China, Chengdu University of Technology, Chengdu, 2014.

[19] I. Cartwright, T. R. Weaver, S. Fulton, C. Nichol, M. Reid, and $\mathrm{X}$. Cheng, "Hydrogeochemical and isotopic constraints on the origins of dryland salinity, Murray Basin, Victoria, Australia," Applied Geochemistry, vol. 19, no. 8, pp. 1233-1254, 2004.

[20] I. Farid, K. Zouari, A. Rigane, and R. Beji, "Origin of the groundwater salinity and geochemical processes in detrital and carbonate aquifers: case of Chougafiya basin (Central Tunisia)," Journal of Hydrology, vol. 530, pp. 508-532, 2015.
[21] R. Yuan, X. Song, Y. Zhang, D. Han, S. Wang, and C. Tang, "Using major ions and stable isotopes to characterize recharge regime of a fault-influenced aquifer in Beiyishui River Watershed, North China Plain," Journal of Hydrology, vol. 405, no. 34, pp. 512-521, 2011.

[22] Q. Guo, Y. Wang, and W. Liu, "Hydrogeochemistry and environmental impact of geothermal waters from Yangyi of Tibet, China," Journal of Volcanology and Geothermal Research, vol. 180, no. 1, pp. 9-20, 2009.

[23] B. Zhu, X. Wang, and P. Rioual, "Multivariate indications between environment and ground water recharge in a sedimentary drainage basin in northwestern China," Journal of Hydrology, vol. 549, pp. 92-113, 2017.

[24] S. Kebede, Y. Travi, T. Alemayehu, and T. Ayenew, "Groundwater recharge, circulation and geochemical evolution in the source region of the Blue Nile River, Ethiopia," Applied Geochemistry, vol. 20, no. 9, pp. 1658-1676, 2005.

[25] W. Kloppmann, P. Négrel, J. Casanova, H. Klinge, K. Schelkes, and C. Guerrot, "Halite dissolution derived brines in the vicinity of a Permian salt dome (N German Basin), evidence from boron, strontium, oxygen, and hydrogen isotopes," Geochimica et Cosmochimica Acta, vol. 65, no. 22, pp. 4087-4101, 2001.

[26] G. Pilla, E. Sacchi, G. Zuppi, G. Braga, and G. Ciancetti, "Hydrochemistry and isotope geochemistry as tools for groundwater hydrodynamic investigation in multilayer aquifers: a case study from Lomellina, Po plain, South-Western Lombardy, Italy," Hydrogeology Journal, vol. 14, no. 5, pp. 795-808, 2006.

[27] M. Zarei, E. Raeisi, B. J. Merkel, and N.-A. Kummer, "Identifying sources of salinization using hydrochemical and isotopic techniques, Konarsiah, Iran," Environmental Earth Sciences, vol. 70, no. 2, pp. 587-604, 2013.

[28] Y. Li, A Study on Hydrogeochemical Characteristics and the Origin of Brine in Lower-Middle Triassic of Sichuan Basin, Chengdu University of Technology, Chengdu, 2015.

[29] X. Zhou, Q. Cao, S. P. Li et al., "Formation of the Ningchang salt spring in Wuxi county of Chongqing," Quaternary Sciences, vol. 34, no. 5, pp. 1037-1043, 2014.

[30] Q. Tang, X. Li, W. Wang, Y. X. Chen, and Y. He, "Correlation analysis of water chemical composition of the lower and middle three salt brine in Sichuan Basin," Peal River, vol. 38, no. 4, pp. 70-73, 2017.

[31] C. Tong, Tectonic Evolution and Oil and Gas Occurrence of the Sichuan Basin, China, Geological Publishing House, Beijing, 1992.

[32] C. G. Tong, "Relationship between Neotectonic movement and structural evolution and gas pools formation of Sichuan Basin," Journal of Chengdu University of Technology, vol. 27, no. 2, pp. 123-131, 2000.

[33] X. H. Sun, Y. F. Hu, C. L. Liu et al., "Argument that brine of salty lake in Sichuan Basin had reached crystallizing point of potash minerals during Triassic: evidence from chemical composition of fluid inclusions in halite," Mineral Deposits, vol. 35, no. 6, pp. 1157-1168, 2016.

[34] Z. W. Yang, A Study on Hydrogeological Feature of the LowerMiddle Triassic of the Midwest of Sichuan Basin, Chengdu University of Technology, Chengdu, 2013.

[35] Y. T. Lin and Z. R. Pan, "Study on density and forming classification of gas field brine," Journal of Salt Lake Research, vol. 9, no. 3 , pp. 1-7, 2001. 
[36] P. Yang, Q. Cheng, S. Xie et al., "Hydrogeochemistry and geothermometry of deep thermal water in the carbonate formation in the main urban area of Chongqing, China," Journal of Hydrology, vol. 549, pp. 50-61, 2017.

[37] D. Gong, The Triassic Salt-Forming Environment, PotashForming Conditions and Genetic Mechanism in Sichuan Basin, Chengdu University of Technology, Chengdu, 2016.

[38] Q. Cao, X. Zhou, H. Zhang et al., "Hydrochemical characteristics and genesis of the subsurface brines in the Wolonghe brine-bearing structure of Sichuan Basin," Geological Bulletin of China, vol. 34, no. 5, pp. 990-997, 2015.

[39] M. Redwan and A. A. Abdel Moneim, "Factors controlling groundwater hydrogeochemistry in the area west of Tahta, Sohag, Upper Egypt," Journal of African Earth Sciences, vol. 118, pp. 328-338, 2016.

[40] O. Abdalla and R. b. Y. Al-Abri, "Factors affecting groundwater chemistry in regional arid basins of variable lithology: example of Wadi Umairy, Oman," Arabian Journal of Geosciences, vol. 7, no. 7, pp. 2861-2870, 2014.

[41] J. H. Tellam, "Hydrochemistry of the saline groundwaters of the lower Mersey Basin Permo-Triassic sandstone aquifer, UK," Journal of Hydrology, vol. 165, no. 1-4, pp. 45-84, 1995.

[42] R. Zhao, Research on the System of Regional Karst Water in the Topographic Gradient Zone of the South Edge of Sichuan Basin, Chengdu University of Technology, Chengdu, 2016, [PhD] (in Chinese).

[43] M. M. Ta, X. Zhou, J. Guo, X. Y. Wang, Y. Wang, and Z. P. Xu, "Some problems related to the occurrence and formation of hot springs," Hydrogeology \& Engineering Geology, vol. 45, no. 1, pp. 165-172, 2018.

[44] S. Karimi, Z. Mohammadi, and N. Samani, "Geothermometry and circulation depth of groundwater in Semnan thermal springs, Northern Iran," Environmental Earth Sciences, vol. 76, no. 19, pp. 1-24, 2017.

[45] M. Kompani-Zare and F. Moore, "Chemical thermometry and origin of the Dalaki mineral springs, Bushehr Province, Iran," Journal of Hydrology New Zealand, vol. 40, no. 2, pp. 189-204, 2001.

[46] R. T. Kimblin, "The chemistry and origin of groundwater in Triassic sandstone and quaternary deposits, Northwest England and some UK comparisons," Journal of Hydrology, vol. 172, no. 1-4, pp. 293-311, 1995.

[47] L. C. Murray and K. J. Halford, Hydrogeologic Conditions and Simulation of Ground-Water Flow in the Greater Orlando Metropolitan Area, East-Central Florida, U.S. Geological Survey, Water-Resources Investigations Report, 96-4181, 1996.

[48] J. Ma, J. He, S. Qi et al., "Groundwater recharge and evolution in the Dunhuang Basin, northwestern China," Applied Geochemistry, vol. 28, no. 28, pp. 19-31, 2013.

[49] T. Xu, E. Xu, and J. Su, A Study of the Occurrence and Hydrochemical Characteristics of the Brines in the Sichuan Basin. (in Chinese), Report 86008-04-02, Second Geological Team of the Bureau of Geology and Mineral Resources of Sichuan Province, Zigong, 1981.

[50] M. X. Chen and Y. W. He, "Nature of geothermal water resources in Huashuiwan, Dayi, Chengdu and the significance of its discovery," Acta Geologica Sichuan, vol. 16, no. 2, pp. 142-146, 1996.

[51] J. Gunn, S. H. Bottrell, D. J. Lowe, and S. R. H. Worthington, "Deep groundwater flow and geochemical processes in limestone aquifers: evidence from thermal waters in Derbyshire,
England, UK," Hydrogeology Journal, vol. 14, no. 6, pp. 868881, 2006.

[52] W. M. Edmunds and P. L. Smedley, "Residence time indicators in groundwater: the East Midlands Triassic sandstone aquifer," Applied Geochemistry, vol. 15, no. 6, pp. 737-752, 2000.

[53] J. M. Gil-Marquez, J. A. Barbera, B. Andreo, and M. Mudarra, "Hydrological and geochemical processes constraining groundwater salinity in wetland areas related to evaporitic (karst) systems, a case study from Southern Spain," Journal of Hydrology, vol. 544, pp. 538-554, 2017.

[54] S. Grassi, N. Kolios, M. Mussi, and A. Saradeas, "Groundwater circulation in the Nea Kessani low-temperature geothermal field (NE Greece)," Geothermics, vol. 25, no. 2, pp. 231-247, 1996.

[55] J. J. Fan, X. F. Jia, Q. Y. Hu, J. Y. Fan, S. Q. Zhang, and C. Zhang, "Potential and suitable conditions evaluation of $\mathrm{CO}_{2}$ storage in the salt water aquifer in the depth of Sichuan Basin," Groundwater, vol. 36, no. 6, pp. 59-63, 2014.

[56] X. Zhou, F. S. Hu, J. T. He, X. S. Wang, and B. Fang, Introduction to Groundwater Sciences, Geological Publishing House, Beijing, 2nd edition, 2015.

[57] Z. Xun, L. Cijun, J. Xiumin, D. Qiang, and T. Lihong, "Origin of subsurface brines in the Sichuan Basin," Groundwater, vol. 35, no. 1, pp. 53-58, 1997.

[58] C. Caetano Bicalho, C. Batiot-Guilhe, J. L. Seidel, S. van Exter, and H. Jourde, "Geochemical evidence of water source characterization and hydrodynamic responses in a karst aquifer," Journal of Hydrology, vol. 450-451, pp. 206-218, 2012.

[59] X. Huang, L. D. Wang, X. Zhou, and Q. Cao, "Geological analysis of the origin of hot springs in a fault-fold belt in the Eastern Sichuan Basin," China Shanghai Land \& Resources, vol. 33, no. 2, pp. 57-61, 2012.

[60] Sichuan Geological Bureau, Sichuan Hydrogeology Collection, Sichuan people's publishing house, Chengdu, 1981.

[61] X. Zhou, X. Wang, J. Han et al., "Evolution of the subsurface K-rich brines in the Triassic carbonates in the Sichuan Basin of China," Groundwater, vol. 56, no. 5, pp. 832-843, 2018.

[62] X. Zhou and C. Li, "Hydrogeochemistry of deep formation brines in the Central Sichuan Basin, China," Journal of Hydrology, vol. 138, no. 1-2, pp. 1-15, 1992. 

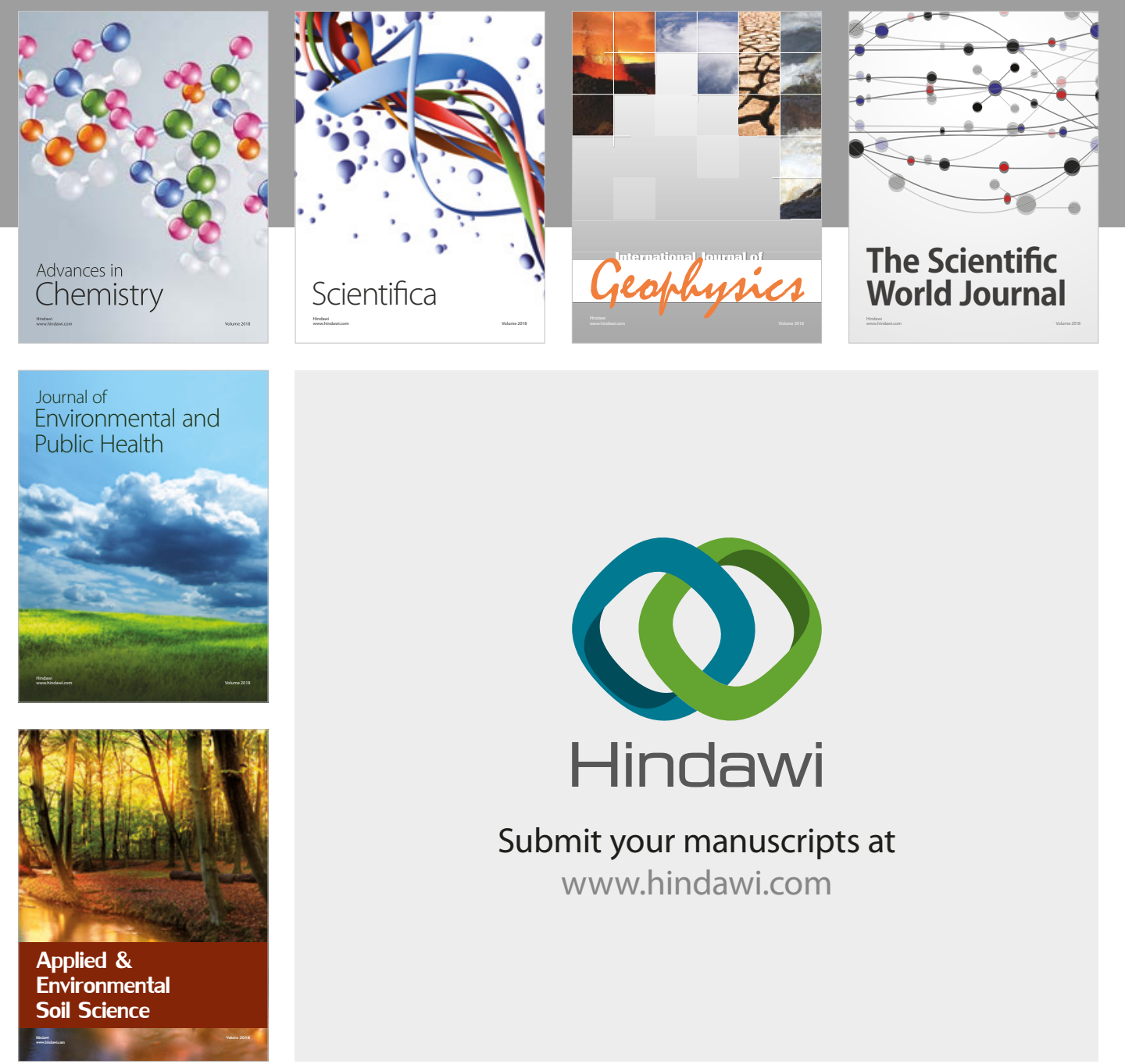

The Scientific

\section{World Journal}
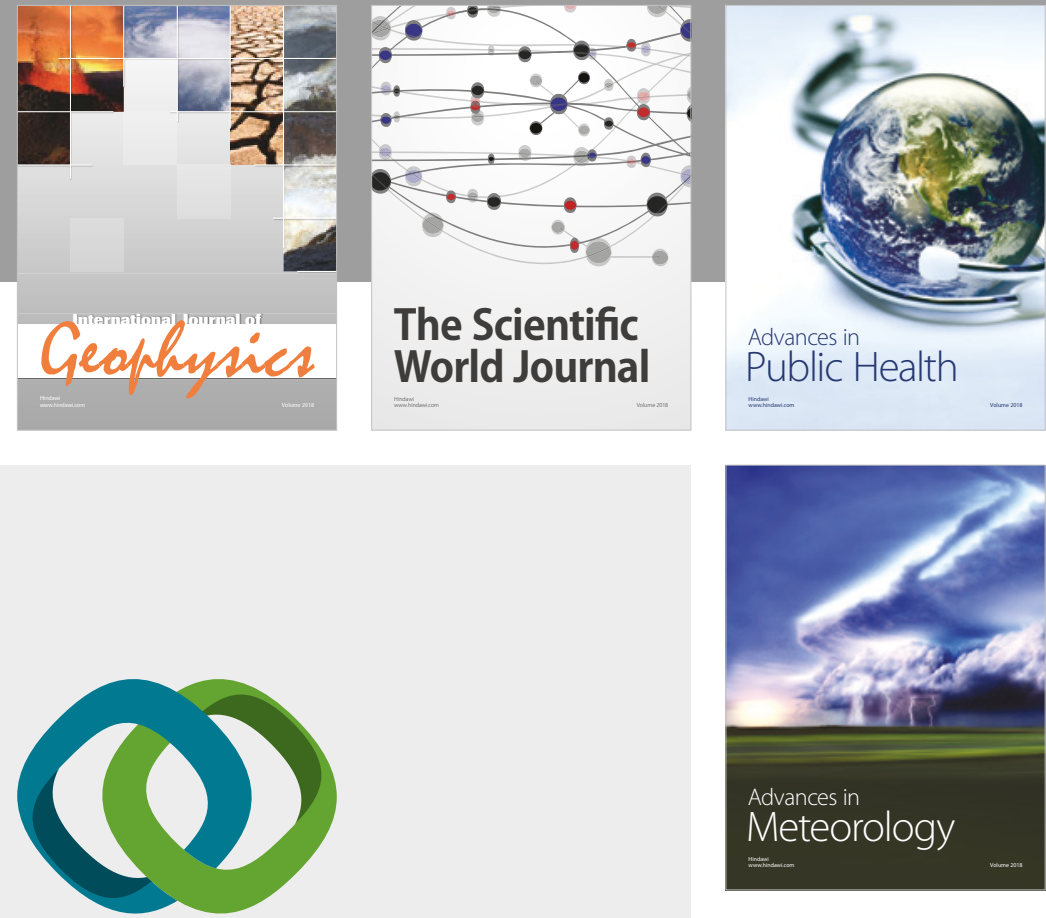

Advan

Public Health

\section{Hindawi}

Submit your manuscripts at

www.hindawi.com
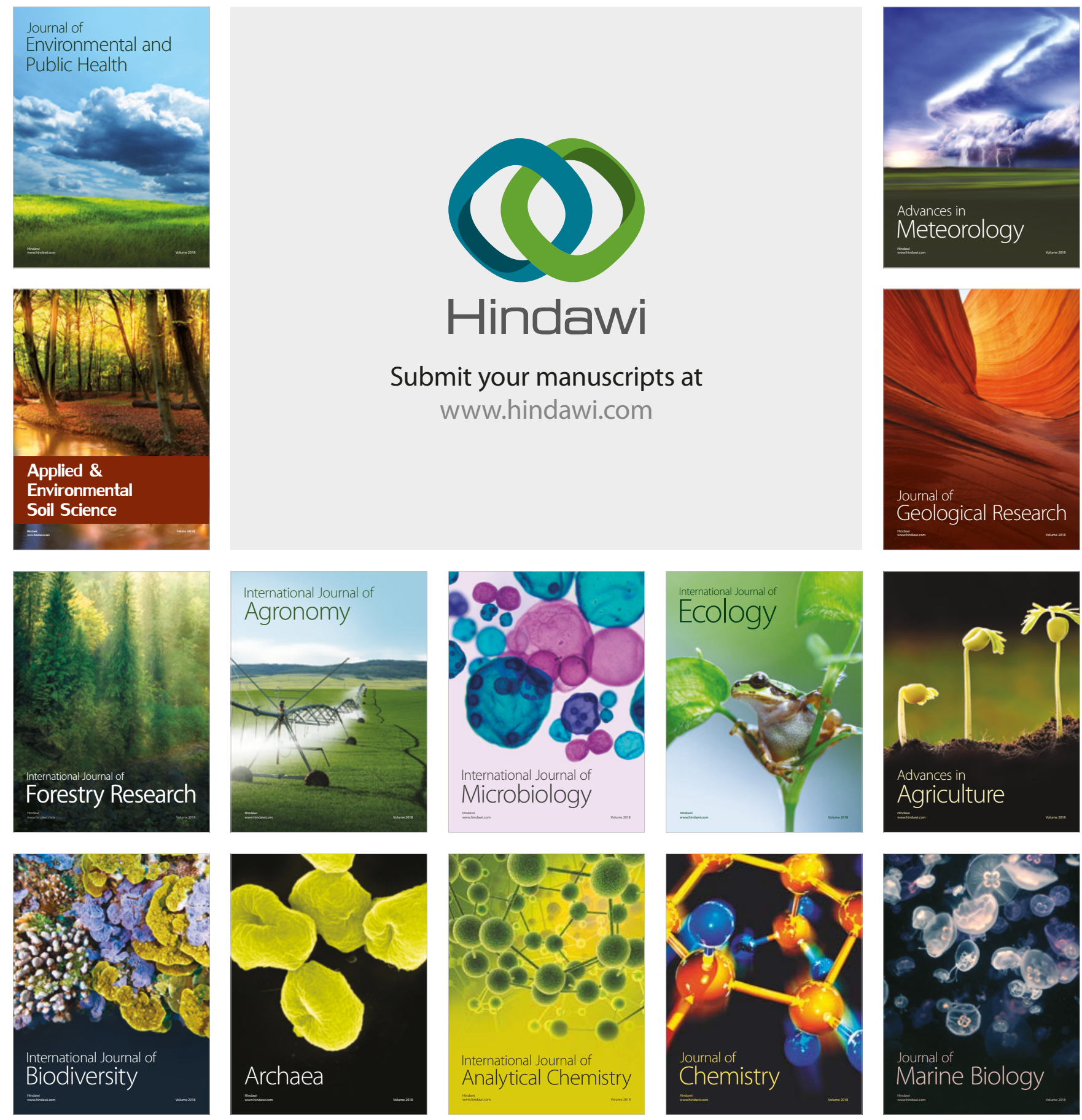